\title{
The resurgence of cultural borders in international finance during the financial crisis: Evidence from Eurozone cross-border depositing
}

Citation for published version (APA):

Kleimeier, S., Sander, H., \& Heuchemer, S. (2014). The resurgence of cultural borders in international finance during the financial crisis: Evidence from Eurozone cross-border depositing. Maastricht University, Graduate School of Business and Economics. GSBE Research Memoranda No. 013 https://doi.org/10.26481/umagsb.2014013

Document status and date:

Published: 01/01/2014

DOI:

10.26481/umagsb.2014013

Document Version:

Publisher's PDF, also known as Version of record

Please check the document version of this publication:

- A submitted manuscript is the version of the article upon submission and before peer-review. There can be important differences between the submitted version and the official published version of record.

People interested in the research are advised to contact the author for the final version of the publication, or visit the DOI to the publisher's website.

- The final author version and the galley proof are versions of the publication after peer review.

- The final published version features the final layout of the paper including the volume, issue and page numbers.

Link to publication

\footnotetext{
General rights rights.

- You may freely distribute the URL identifying the publication in the public portal. please follow below link for the End User Agreement:

www.umlib.nl/taverne-license

Take down policy

If you believe that this document breaches copyright please contact us at:

repository@maastrichtuniversity.nl

providing details and we will investigate your claim.
}

Copyright and moral rights for the publications made accessible in the public portal are retained by the authors and/or other copyright owners and it is a condition of accessing publications that users recognise and abide by the legal requirements associated with these

- Users may download and print one copy of any publication from the public portal for the purpose of private study or research.

- You may not further distribute the material or use it for any profit-making activity or commercial gain

If the publication is distributed under the terms of Article $25 \mathrm{fa}$ of the Dutch Copyright Act, indicated by the "Taverne" license above, 
Stefanie Kleimeier,

Harald Sander, Sylvia Heuchemer

The Resurgence of Cultural

Borders in International

Finance during the Financial

Crisis: Evidence from

Eurozone Cross-Border

Depositing

$\mathrm{RM} / 14 / 013$

\section{GSBE}

Maastricht University School of Business and Economics

Graduate School of Business and Economics

P.O Box 616

NL-6200 MD Maastricht

The Netherlands 
The Resurgence of Cultural Borders in International Finance during the Financial Crisis:

Evidence from Eurozone Cross-Border Depositing

\author{
Harald Sander $^{\mathrm{a}, \mathrm{b}, \mathrm{e}}$, Stefanie Kleimeier ${ }^{\mathrm{c}, \mathrm{e}^{*}}$, and Sylvia Heuchemer ${ }^{\mathrm{d}}$ \\ a Professor of Economics and International Economics, Faculty of Economics and Business \\ Administration, Cologne University of Applied Sciences, Claudiusstr.1, 50678 Köln, Germany \\ ${ }^{b}$ Professor of Economics at Maastricht School of Management, Endepolsdomein 150, 6229 EP \\ Maastricht, The Netherlands \\ c Associate Professor of Finance, School of Business and Economics, Maastricht University, \\ Tongersestraat 53, 6211 LM Maastricht, The Netherlands \\ ${ }^{d}$ Professor of Economics and Quantitative Methods, Faculty of Economics and Business Administration, \\ Cologne University of Applied Sciences, Claudiusstr.1, 50678 Köln, Germany \\ ${ }^{e}$ Fellow, Graduate School of Business and Economics, Maastricht University, Tongersestraat 53, 6211 \\ LM Maastricht, The Netherlands
}

\begin{abstract}
:
In this paper, we demonstrate that cultural borders in international finance resurge during financial crises.

To investigate the role of cultural borders during both tranquil and crisis periods, we employ a unique data set that focuses on Eurozone cross-border depositing in a gravity-model framework. We provide evidence that cultural distance limits international financial integration. However, cultural borders lost influence during a "Europhoria" phase after the introduction of the Euro notes in 2002, indicating that confidence in the new currency helps to overcome cultural borders. In contrast, cultural borders have severely limiting effects during crisis periods.
\end{abstract}

Keywords: culture, trust, financial crisis, banking market integration, cross-border deposits, gravity model, European single market

JEL Classification: C23, F36, G15, G21, Z10

* Corresponding author: Tel: +31-43-3883733, fax: +31-43-3884875, E-mail address: s.kleimeier@maastrichtuniversity.nl 


\section{INTRODUCTION}

In this paper, we demonstrate that cultural differences across countries constitute important trade costs in cross-border finance. Cultural differences act as invisible borders that limit financial integration more than could be expected from purely economic reasoning. We show that this limiting effect is more severe during financial crises than during tranquil periods. In other words, financial crises heighten the cultural barriers to financial integration. To scrutinize the transmission channels from culture to financial integration, we focus on cross-border depositing in the Eurozone during the 1999-2011 period. The existence of a single currency and homogenized single banking market legislation provide us with a unique setting in which the channels of cultural influences during tranquil and crisis periods can be isolated.

The resistance of banking markets to integration has perplexed European policymakers over the past decade (see Barros et al. 2005, Dermine 2006, Kleimeier and Sander 2007, Walkner and Raes 2005). As in merchandise trade, the law of one price was and is the benchmark for an integrated market (Adam et al. 2002, Baele et al. 2004, Kleimeier and Sander, 2006). However, the retail banking market remains far from this goal, as interest rate differences persist across countries. ${ }^{1}$ Furthermore, given the variety of deposit products offered within and across countries, the actual differences and thus the arbitrage opportunities may be even higher than simple price differences suggest. Despite these arbitrage opportunities, cross-border deposits from Eurozone depositors account for only $5.0 \%$ of total deposits held in Eurozone banks in 2011, compared to 5.5\% in 1999. Trade costs in the broadest sense are the prime candidate for explaining the low level of cross-border depositing and the absence of arbitrage. Our approach provides a theoretically founded explanation by highlighting the role of cultural differences in limiting international exchange. By adopting a broad view on trade costs and their influence on crossborder depositing, we contribute to an emerging literature that highlights the importance of culture and

\footnotetext{
${ }^{1}$ The average deposit interest rate difference (measured in absolute terms) across all 12 initial Eurozone countries over the sample period 1999-2011 is 0.85 percentage points, with a standard deviation of 1.0 . Interest differences declined from nearly 2.0 percentage points in 1999 to under 0.5 percentage points in 2004 to 2008 . However, since the onset of the crisis, interest rate differences have again risen to nearly 1.0 percentage point.
} 
cultural differences in international economic exchange (see e.g., Ekinci, Kalemli-Ozcan, and Sorensen 2007, Grosjean 2011a, Grosjean 2011b, Guiso, Sapienza, and Zingales 2009, Heuchemer, Kleimeier, and Sander 2009, Siegel, Licht, and Schwartz 2011, Stulz and Williamson 2003). These studies show that culture, cultural differences, trust in others, egalitarianism, the heritage of the legal system, institutional quality, and confidence in institutions can be both important drivers of and barriers to economic exchange in general and of cross-border finance in particular.

Our analysis builds on studies that estimate trade cost effects in gravity models of international trade. We hence argue firstly that cultural differences across countries constitute trade costs between any pair of countries. Second, we reason that differences in trust levels are a theoretically appealing proxy for cultural heterogeneity and demonstrate that these differences constitute empirically relevant cultural borders in cross-border depositing. ${ }^{2}$ Third, we treat cultural differences as relative concepts and argue that controlling for remoteness is crucial in addressing the impact of culture on economic exchange. Empirical trade analysts have controlled for remoteness to arrive at reliable estimates for the role of physical distance (e.g., Frankel 1997, Wei 1996). With respect to culture, being very different from one trading partner will matter less if one is even farther away from all other potential partners, whereas small cultural differences can make all the difference when one's favorite trading partners are culturally even closer to you. Fourth, and consequently, the consensus in the empirical trade literature is that these relative trade costs have to be estimated in gravity models that account for this so-called multilateral resistance (Anderson and van Wincoop 2003 and 2004) by utilizing country-specific fixed effects. ${ }^{3}$

We investigate the transmission channels from culture to international finance using a set of otherwise confidential bilateral Eurozone cross-border depositing data obtained from the Bank of International Settlements (BIS) covering the period from 1999 to 2011. To uncover the impact of culture

\footnotetext{
${ }^{2}$ For recent studies using trust differences as a measure of cultural heterogeneity, see Grosjean (2011a) and Heuchemer, Kleimeier, and Sander (2009).

${ }^{3}$ Alternatively, a recently developed first-order log-linear Taylor approximation for gravity models of international trade by Baier and Bergstrand (2009) can also control for and directly estimate the impact of relative cultural differences. Because the Taylor series expansion is usually centered on a symmetric world and also highly sensitive to how it is centered, we refrain from using this approach. The right-skewed distribution of the dependent variable violates the central simplifying assumption of this approach.
} 
on financial integration during the financial crisis, we disaggregate our data into sub-periods before and after 2007 and furthermore estimate gravity models for three-year moving average periods. We thus contribute to the ongoing discussion of the effects of crises on financial (dis-)integration. Financial crises are often associated with a retrenchment of cross-border finance. However, most studies focus on international lending ${ }^{4}$ and document a nationalistic turn (Rose and Wieladeck 2011) or flight home effect (Giannetti and Laeven 2012, Hildebrand, Rocholl, and Schulz 2012). Corresponding evidence for the international retail deposit market is limited, except for the study by Kleimeier, Sander, and Heuchemer (2013), who show that retail customers move deposits abroad in response to a crisis in their home country, thus exhibiting a "flight to quality" behavior that, according to Giannetti and Laeven (2012), is absent in bank behavior.

While our findings demonstrate that cultural heterogeneity in the Eurozone, measured as differences in general social trust levels, limits cross-border depositing in the region, we also show that over time, this limiting effect has become weaker, most likely indicating some "Europhoria," e.g., Euro euphoria during the first years after the Euro notes went into circulation. Confidence in the stability of the new common currency may have helped to reduce the impact of cultural borders. The financial crisis, however, leads to a strong resurgence of the role of cultural differences.

The paper proceeds as follows: in Section 2, we discuss the relevance of culture to international finance. In Section 3, we introduce our theoretically based empirical gravity model. Section 4 provides a brief description of the data. Section 5 presents our results, and in Section 6, we examine their robustness to a variety of alternative specifications and estimation procedures. Section 7 concludes.

\footnotetext{
${ }^{4}$ Cetorelli and Goldberg (2011), Herrmann and Mihaljek (2010), Milesi-Ferretti and Tille (2011), and Takats (2010) analyze cross-border lending, whereas Cetorelli and Goldberg (2011 and 2012), Milesi-Ferretti and Tille (2011), Peek and Rosengren (2000), Popov and Udell (2012), and Rose and Wieladek (2011) focus on local lending by foreign offices.
} 


\section{ACCOUNTING FOR CULTURE IN INTERNATIONAL FINANCE}

How can one best account for culture in an empirical analysis of the impact of culture on international exchange, especially on international finance? We approach this question in two steps. First, we define what we mean by culture. Second, we discuss the choice of valid and reliable indicators of culture that could have an impact on economic exchange.

We follow Guiso, Sapienza, and Zingales (2006: 23), who define culture as "those customary beliefs and values that ethnic, religious, and social groups transmit fairly unchanged from generation to generation." In a similar vein, Grosjean (2011a: 504) argues that "cultural persistence and cultural heterogeneity are two sides of the same coin" and shows that cultural change is very slow. Thus, very distant major historical events still matter for present cultural differences, which in turn influence today's economic structures, transactions, and financial development in Europe (Grosjean 2011b). Moreover, such a slowly-changing cultural variable can be taken as an exogenous variable in economic studies of a somewhat shorter horizon.

What variable(s) would thus be suitable to measure culture? The simplest proxies for cultural proximity are dummy variables for religious differences and common language. Although easily available, both proxies capture only a small share of cultural differences. ${ }^{5}$ Two broader measures of culture dominate the business and economic literature on culture: management science prefers Hofstede's (1980) cultural dimensions (or at least a variant of them), whereas the economic literature often concentrates on trust as the most important trait of culture for the analysis of economic exchange. Beginning with the former, Hofstede identifies four different cultural dimensions: power distance measures the distribution of power in organizations and institutions; individualism is an indicator for the relationships of individuals with groups; masculinity concerns the distribution of roles between genders; and uncertainty avoidance measures tolerance for unknown situations. ${ }^{6}$ In contrast, Casson (2006)

\footnotetext{
${ }^{5}$ For a more detailed analysis of the impact of linguistic traits and differences in international trade, see Melitz (2008).

${ }^{6}$ In a cross-sectional study, Tang and Koveos (2008) show that masculinity and uncertainty avoidance are often invariant to economic development as measured by GDP per capita, but individualism increases and power distance
} 
theoretically identifies four major dimensions of culture: individualism, pragmatism, the level of tension, and the degree of trust. He argues that these and Hofstede's (1980) cultural dimensions correspond broadly with the notable exception of power distance, which might be better captured by the degree of trust. Pragmatism relates to low uncertainty avoidance in Hofstede's terminology, and its opposite is proceduralism, whereas a high level of tension corresponds to Hofstede's masculinity.

Therefore, the economic literature seems to converge on the point that trust is an important dimension of culture. From the perspective of our study, trust has a crucial advantage over at least some of Hofstede's cultural dimensions: it is directly linked with economic exchange. As emphasized by Arrow (1972: 357), "[v]irtually every commercial transaction has within itself an element of trust, certainly any transaction conducted over a period of time." Moreover, trust can directly reduce transaction costs because firms need less time to investigate the trading partner. Finally, it has been shown that differences in social trust are persistent and often relate back to long past historical events. For example, Grosjean (2011a) links a reduction in cultural distances in terms of social trust with long past historical events, e.g., being governed by the same empire.

Several studies use a trust variable to quantify its positive impact on economic exchange. These studies differ in the way they model the influence of trust. In principle, there are three possibilities: (i) to focus on the impact of the general trust level (e.g., Algan and Cahuc 2010, Ekinci, Kalemli-Ozcan, and Sorensen 2007, Knack and Keefer 1997, Zak and Knack 2001); (ii) to consider bilateral trust extended from a truster to a trustee (Guiso, Sapienza, and Zingales 2009); and (iii) to investigate differences in general trust levels as a proxy for cultural differences (Grosjean 2011a, Heuchemer, Kleimeier, and Sander 2009). In the first two cases, the literature provides evidence of a positive association between higher levels of trust and bilateral trust and economic exchange and performance. In the third case - and in line with the literature on cultural differences following Hofstede - one expects less economic exchange with greater trust differences between any pair of economic agents.

decreases with GDP per capita - at least after it has surpassed a certain threshold level. Consequently, Hofstede's (1980) variables do not fully fit our definition of slowly changing culture but can be viewed as a good approximation when applying them for a shorter period of time. 
We focus here on the latter aspect: trust as a proxy for an important cultural dimension and the limiting effects of these trust differences. The choice is warranted given our focuses on bilateral crossborder depositing in which cultural differences can be an important element of trade costs. Although an overall measure of cultural differences following Hofstede (1980) would - at least in theory - cover all elements of culture in a single measure and would therefore reflect the complexity of the culture concept, we do not perceive strong arguments in favor of Hofstede's masculinity as a determinant of economic exchange in financial markets. The same is true for power distance, and we agree with Casson (2006) that trust is a better replacement. Complex measures may therefore not be well suited, supporting the skeptical view of Shenkar (2001) about using an aggregate cultural index, while individual components such as individualism and uncertainty avoidance as measures of risk aversion, which according to Sapienza, Toldra, and Zingales (2007) are not reflected in trust, may be too narrow in focus.

Alternatively, bilateral trust, in the spirit of Guiso, Sapienza, and Zingales (2009), would also be of great interest in exploring the role of cultural priors in cross-border activities. ${ }^{7}$ Unfortunately, the latest available bilateral data date back to 1996 . In contrast to trust levels, bilateral trust is time-variant, and participants update their trust based on recent experiences. Thus, bilateral trust data for 1996 do not properly reflect the situation in the Eurozone from 1999 to 2011.

In sum, and reflecting the advantages and disadvantages of different proxies for cultural differences, we favor trust differences as a measure of cultural heterogeneity: it is theoretically the most appealing concept, well established in the literature, evolving slowly and thus less vulnerable to endogeneity problems, and - last but not least - readily available from regular World Value Surveys (WVS).

\footnotetext{
${ }^{7}$ Guiso, Sapienza, and Zingales (2009) document cultural biases for international trade, foreign direct investment and international financial transactions by showing that bilateral trust has a significant impact on cross-border economic exchange. They interpret bilateral trust as cultural priors that affect economic exchange more than economic country characteristics would suggest. In their view, bilateral trust is thus not only a function of objective country characteristics but also of deeply rooted historical, cultural, and even genetic differences. However, the authors realize that bilateral trust is endogenous, as it may increase (or in cases of bad experiences, decrease) with economic exchange. When instrumenting bilateral trust with its cultural determinants, they find an even stronger estimated effect of bilateral trust.
} 


\section{A GRAVITY ANALYSIS OF CULTURAL TRADE COSTS}

Cultural differences impose bilateral trade costs because differences in languages, customs, traditions, law systems, or business practices raise information and communication costs. To analyze the influence of cultural trade costs on cross-border depositing, we employ a gravity-model approach. Gravity models were long considered pure physical analogues to Newton's law of gravity because they had no theoretical foundation. Due to the work of, for example, Anderson (1979), Anderson and van Wincoop (2003, 2004), Bergstrand (1985, 1989), and Deardorff (1998), the theoretical foundation of gravity models has steadily improved such that the gravity approach is now widely accepted as a theoretical and econometrical framework for studying transactions over space. Most recently, the gravity approach has been applied to analyze international financial transactions (e.g., Aviat and Coeurdacier 2007, Buch 2005, Buch and Lipponer 2007, Coeurdacier and Martin 2009, Heuchemer, Kleimeier, and Sander 2009, Lane and MilesiFeretti 2004, Martin and Rey 2004, Okawa and van Wincoop 2012, Portes and Rey 2005). This rapidly evolving literature sheds light on the distance puzzle found in cross-border finance and international banking, which, despite the weightlessness of financial products, obey the law of gravity.

However, most of these studies address cross-border equity flows or holdings and thus equity portfolio diversification. For our analysis of cross-border depositing, we find it more appropriate to build directly on the approaches of Anderson and van Wincoop (2003, 2004), which were originally derived for international trade in goods. These approaches assume a monopolistic competitive market structure with heterogeneous goods. The approaches are also frequently used in industrial organization studies of banking, dating back to Salop (1979), who introduces product differentiation by means of spatially differentiated markets. More recent applications are provided by, for example, Matutes and Vives (2000), Novo-Peteirio (2009), and Pita Barros (1999). The representative depositor can be considered as one who enjoys variety and prefers to have deposits in several banks because of additional features that come with a bank account, e.g., access to loans, credit cards, the cost of making transfers within or without networks of banks, etc., as described by Matutes and Vives (2000). Consequently, our gravity model implicitly and 
by design controls for deposit product variety as an important reason for depositors to hold several (domestic and) foreign accounts. ${ }^{8}$

When treating deposits as differentiated goods, we can employ a general equilibrium model that highlights the role of multilateral resistance. According to the key finding of Anderson and van Wincoop (2003), traditional gravity models overstate the influence of bilateral trade barriers because these models focus purely on bilateral resistance and completely ignore the third-country effects that appear as soon as countries operate in a multilateral world: bilateral trade flows are thus not only determined by the absolute trade barriers between two countries but also by their bilateral trade barriers relative to their average trade barriers, the so-called multilateral resistance.

We derive our theoretical model from Anderson and van Wincoop's (2003) one-sector multicountry general equilibrium model. ${ }^{9}$ Three key elements are essential for the theoretical foundation: (1) the deposit market has a monopolistically competitive structure with banks that offer products that are differentiated by origin, (2) optimizing consumers derive utility from consuming a variety of domestic and foreign deposit products, and (3) cross-border depositing entails trade costs - understood in the broadest sense. Based on this framework, the gravity equation for cross-border depositing is as follows:

$$
X_{o d}=D_{d} E_{o}\left(\frac{t_{o d}}{P_{o} \Pi_{d}}\right)^{1-\sigma}
$$

Cross-border depositing $(X)$ from the origin (depositor) country $o$ to the destination (bank) country $d$ depends on the economic masses, here measured by the size of the deposit markets in the destination $\left(D_{d}\right)$ and origin $\left(E_{o}\right)$ country, respectively, as well as the size of the bilateral trade costs $\left(t_{o d}\right)$ relative to average trade barriers that the origin $\left(P_{o}\right)$ and destination countries $\left(\Pi_{d}\right)$ face with all of their trading partners. The latter two price indexes express the multilateral resistance and summarize the average trade costs between

\footnotetext{
${ }^{8}$ Brüggemann, Kleinert, and Prieto (2012) develop a gravity model based on product differentiation for international bank loans. Niepmann (2013) develops a gravity model for both loans and deposits. Her model is based on a bank perspective. In contrast, our model is based on the depositor's portfolio decision, which in our particular case of retail depositing is more appropriate.

${ }^{9}$ We focus on a one-sector model in which consumers have CES preferences with common elasticity among the variety of domestic and foreign deposit products. The derivation of the theoretical model is available in Appendix A.
} 
a country and all of its trading partners. The parameter $\sigma$ is the constant elasticity of substitution across heterogeneous deposits with $\sigma>1$.

To estimate the gravity model, we convert Equation (1) into a log-linear version (2) and allow for variation in the variables over time $t$ :

$$
\ln X_{o d t}=\ln D_{o d t}=\ln D_{d t}+\ln E_{o t}+(1-\sigma) \ln t_{o d t}-(1-\sigma) \ln P_{o t}-(1-\sigma) \ln \Pi_{d t}+\varepsilon_{o d t}
$$

When estimating Equation (2), we follow our theoretical model as closely as possible. We hypothesize that the log of the observed cross-border depositing $\left(D_{\text {odt }}\right)$ is equal to the true amount of cross-border deposit holdings $\left(\ln X_{\text {odt }}\right.$ ). Furthermore, we need to define the variables that represent the size of the national deposit markets $D_{d t}$ and $E_{o t}$. We use the size of the deposit market in the destination country $d$ including domestic and foreign deposits as our proxy for $D_{d t}$. We measure $E_{o t}$ as the sum of foreign and domestic deposits made by the residents of origin country $o$.

We model the bilateral trade costs $t_{\text {odt }}$ as a function of observable cost proxies $z_{\text {odt }, m}(m=1, \ldots, M)$ :

$$
t_{\text {odt }}=z_{o d t}^{\gamma_{1}} \cdot \exp \left(\gamma_{2} z_{o d t, 2}+\gamma_{3} z_{o d t, 3}+\ldots+\gamma_{m} z_{o d t, m}\right)
$$

The price levels $P_{o t}$ and $\Pi_{d t}$, which are not observable, summarize the remoteness of one country to all of its trading partners. If we ignored the influence of the so-called multilateral resistance, our estimates would suffer from an omitted variable bias. ${ }^{10}$ Following Anderson and van Wincoop (2004) and Feenstra (2004), we use simple country dummies to control for $P_{o t}$ and $\Pi_{d t}$ and thus estimate a Least Squares Dummy Variable (LSDV) model. However, because we also estimate the gravity model over time, we additionally need to control not only for time effects affecting all countries simultaneously, but also for the interaction of time and country effects. The latter reflect any county-specific changes in inward and outward multilateral resistance over time. In principle, it is possible to explain these changes by introducing explanatory variables, such as risk-return differences, bilateral trade, the share of the migrant population, etc., but this potentially introduces serial correlation and multicollinearity problems into the

\footnotetext{
${ }^{10}$ See Baldwin and Taglioni (2006). Baldwin and Taglioni (2006) suggest including time-varying country-pair fixed effects. However, if we used this fixed-effects approach, we would not be able to estimate and quantify the influence of country-pair specific variables in which we are highly interested.
} 
estimation. Therefore, the cleanest approach to isolate the impact of cultural differences on cross-border depositing is to use a full set of country, time and time-country interaction dummies in the spirit of Baldwin and Taglioni (2006) in a parsimonious gravity model.

\section{DATA}

Cross-border depositing occurs when a bank in one country receives a deposit from a customer who resides in another country. ${ }^{11}$ The BIS' Locational Banking Statistics are uniquely suited to analyze such cross-border deposits because they are - similar to balance-of-payments data - based on the principle of residence. We utilize customized and confidential data made available by the BIS, which are bilateral, e.g., disaggregated by the reporting (e.g., destination) country and the vis-à-vis (e.g., origin) country. ${ }^{12}$ We use annual data on outstanding cross-border deposits from 1999 to 2011 to quantify the retail crossborder deposits $D_{\text {odt }}$ outside the interbank market, i.e., deposits made by households and non-financial corporations. The data sample covers the initial Eurozone member countries of Austria, Belgium, Finland, France, Germany, Ireland, Italy, Luxembourg, the Netherlands, Portugal, and Spain, plus Greece. ${ }^{13}$

Tables 1 and 2 provide initial insights into the structure and dynamics of cross-border depositing of Eurozone banks and depositors. Panel A of Table 1 illustrates how attractive the different national banking markets are to cross-border deposits from depositors located in other Eurozone countries. Banks in Germany, Luxembourg, and Belgium attract the most deposits, with an annual volume of $€ 89.0$ bn, $€$ 76.2 bn, and $€ 64.5$ bn in 2011, respectively. Looking at cross-border deposits in percent of total deposits indicates - not surprisingly - that this part of the financial sector is especially important in Luxembourg, followed by Belgium and Ireland with $33.1 \%, 14.4 \%$, and $12.3 \%$ of total deposits, respectively. In

\footnotetext{
${ }^{11}$ A cross-border deposit is made when a customer who lives in country A deposits money at an office of a bank that is located in country B. As long as the bank's office is located in country B, such a deposit is cross-border, independent of whether the headquarters of the bank is located in country A or B.

${ }^{12}$ Our confidential data are consistent with the more aggregated, publicly available Tables $3 \mathrm{~b}$ and $7 \mathrm{~b}$ of the BIS' Locational Banking Statistics.

${ }^{13}$ Data on cross-border deposits received by banks in Greece, Italy, and Portugal are only available for 2003-2011, 2007-2011, and 1999-2008, respectively. However, data on cross-border deposits made by depositors from Greece, Italy, and Portugal are available for all years.
} 
contrast, Greek and Finish banks receive few deposits from other Eurozone countries, both in total and relative terms. Panel B of Table 1 illustrates the depositors' perspective. Depositors in the Netherlands, Luxembourg, Belgium, and Ireland deposit substantial amounts abroad, both in absolute and relative terms. In contrast, the average annual cross-border deposit volumes of $€ 95.2$ bn and $€ 35.6$ bn that German and French depositors, respectively, shift to other Eurozone countries account for only a small fraction of their total deposits. Whereas Table 1 looks at the origin and destination country as a whole, Table 2 focuses on bilateral cross-border deposits. The total amount of cross-border deposits between depositors in one Eurozone country and banks in another Eurozone country increased from $€ 190$ bn in 1999 to $€ 496$ bn in 2011 , with a peak of $€ 487$ bn in 2008 . However, bilateral cross-border deposit volumes vary substantially across country pairs. Although on average, bilateral cross-border deposits amount to $€ 685$ million, deposits constitute only $€ 26$ million in the bottom $25 \%$ of all Eurozone country pairs but $€ 427$ million in the top $25 \%$ of all Eurozone country pairs. A comparison of the mean and median furthermore indicates that the distribution is skewed to the right. Between most Eurozone countries, cross-border deposit volumes are small, but a few country pairs dominate with extremely high volumes. This result is in line with Table 1, which shows that cross-border deposits are much more important to depositors and banks in countries such as Luxembourg or Ireland than in countries such as Finland or Greece. In sum, both tables indicate the importance of modeling cross-border banking on a bilateral level within a gravity approach rather than the commonly adopted aggregate perspective. ${ }^{14}$

[Insert Tables 1 and 2 about here]

\footnotetext{
${ }^{14}$ Although we thus address one important source of aggregation bias, our analysis is still limited by the nonavailability of regional deposit data because people living closer to a common border are more likely to engage in cross-border depositing. We address this potential bias by controlling for a common border and other demographic factors.
} 
We consider a large set of proxies for cultural distance. ${ }^{15}$ We first use both Hofstede's (1980) cultural dimensions (CULTURAL DISTANCE ${ }_{\text {HOFSTEDE) }}$ ) as well as Casson's approach (CULTURAL DISTANCE $_{\text {CASSON }}$ ) to measure cultural differences as Euclidean distances. Hofstede's cultural proxy is based on all four cultural dimensions, namely uncertainty avoidance, power distance, individualism, and masculinity. For Casson's cultural proxy, we use Hofstede's cultural dimensions, but in line with the theoretical literature, we replace power distance with a trust variable. Trust is measured by the responses to the WVS question: “[G]enerally speaking, would you say that most people can be trusted?" In the spirit of the influential paper by Stulz and Williamson (2003), we also crosscheck the impact of a COMMON LANGUAGE and RELIGIOUS DIFFERENCES. Finally, we arrive at and define our preferred proxy for cultural heterogeneity CULTURAL DISTANCE ${ }_{\text {TRUST, }}$, measured as the Euclidian distance of trust between any pair of countries. ${ }^{16}$ Table A2 in the Appendix B provides the descriptive statistics for our

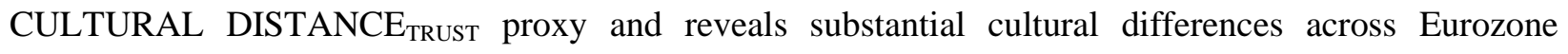
countries. As Panel A shows, trust levels are highest in Finland and the Netherlands and lowest in Portugal. These countries are consequently culturally more distant from the rest of the Eurozone, as

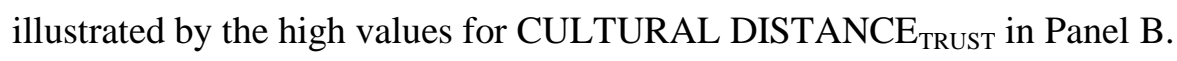

The gravity literature suggests proxies for the size of the deposit market and bilateral trade costs such as physical distance and the existence of a common border. The relative attractiveness of a deposit market can be influenced by the efficiency, depth, and breadth of financial markets. Therefore, controlling for the size of both the origin and destination country's deposit markets as a crude proxy for the sophistication of the deposit market is essential. It is the distinguishing feature of gravity models that they explicitly use market size variables. The inclusion of these variables reflects that the gravity models assume heterogeneous goods and - as in the new trade theory developed by Krugman (1980) - agents

\footnotetext{
${ }^{15}$ These and all other variables used are described in detail in Table A1 in the Appendix B.

${ }^{16}$ According to Sapienza, Toldra, and Zingales (2007: 3), the act of trusting can best be understood "as the combination of the belief in other people's trustworthiness and the specific preferences of the sender (risk aversion, reciprocity, altruism)," and the WVS measure primarily captures the belief-based component of the sender's behavior. The WVS data show that trust is evolving slowly, and the notably wide differences in the level of trust across countries can survive for a longer period of time. We therefore conclude that the trust data that we obtained for 1999 from the fourth wave of the WVS are a good approximation of CULTURAL DISTANCE TRUST. $_{\text {. }}$
} 
engage in intra-industry trade. In our case, this means that we control for the size of both deposit markets and for the fact that deposits are crossing borders in both directions to take advantage of variety in deposit products. To measure the market size in the destination country $\left(D_{d t}\right)$, we use all such deposits held in destination country $d$ by domestic, e.g., resident and non-resident, depositors from all origin countries $o$ worldwide. The size of the deposit market in the origin country represented by $E_{o t}$ and its empirical proxy, TOTAL DEPOSITS $_{\mathrm{ot}}$, is calculated by adding the total deposits of residents of country $o$ to the total value of cross-border deposits made by residents of country $o$ in all other destination countries $d$ worldwide. ${ }^{17}$ DISTANCE is defined as the distance in km between the capital cities of country $o$ and $d$. With respect to the role of a common border, we prefer a measure of the length of the land border between the origin and destination country (COMMON BORDER LENGTH) to the standard, but crude, common border dummy.

\section{RESULTS}

\subsection{The Baseline Model}

Our empirical strategy is as follows. Because cross-border deposits are a part - and in some cases, quite a substantial part - of the empirical $D_{d t}$, we redefine our dependent variable as $D_{o d t} / D_{d t}$ to avoid an endogeneity bias. Then, we first identify the relevant cultural distance proxies within a standard gravity model estimated according to Equation (2) with a full set of time, country, and time-country interaction dummies. Second, we estimate the model for different crisis and non-crisis periods to identify possible changes in the impact of cultural differences. Third, this approach allows us to directly test our hypothesis of an increasing role of cultural differences in the banking crisis (2008-2011) and a more narrowly defined Euro crisis period (2010-2011). Finally, we crosscheck whether our estimates suffer from serial correlation problems by re-estimating our final model with data averaged over 3-year rolling sub-periods

\footnotetext{
${ }^{17}$ This reflects the portfolio decision problem faced by Eurozone depositors, who will have to decide whether to deposit at home, in another Eurozone country, or in the rest of the world. For our TOTAL DEPOSITS proxy, the destination country range of worldwide cross-border deposits is limited to BIS reporting countries.
} 
as well as averaged over the different pre-crisis and crisis sub-periods, in the spirit of Bertrand, Duflo, and Mullainathan (2004).

In Table 3, we report the selection process for the various cultural distance variables using a basic gravity model that concentrates on the classical gravity variables: economic masses, distance, and common borders. The last two act as a rough measure for all types of trade costs. The reported regressions use a standard DISTANCE measure of the physical distance between the capital cities of any country pair and are estimated with a full set of country and time dummies. The first regression, which contains only classical gravity variables, confirms that despite the weightlessness of deposits, Eurozone cross-border deposits obey the law of gravity with a DISTANCE coefficient of -0.61 and a COMMON BORDER LENGTH coefficient of 0.36 . The coefficient for the size of the depositors' country home is significant and has a plausible value of 0.80 . The remaining regressions test the various cultural proxies. They indicate that neither the simple language and religion dummies nor the complex culture variables of the Hofstede and Casson type can validate the impact of cultural differences on international transactions. ${ }^{18}$ In

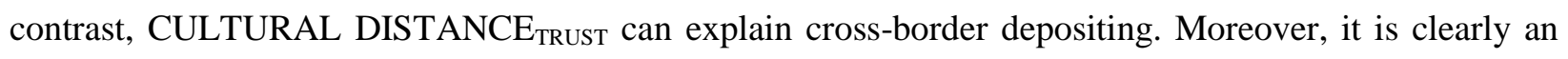
exogenous variable, so our approach does not suffer from a potential endogeneity bias, and thus, CULTURAL DISTANCE ${ }_{\text {TRUST }}$ becomes our preferred proxy for CULTURAL DISTANCE.

[Insert Table 3 about here]

\footnotetext{
${ }^{18}$ For completeness, we also test the impact of BILATERAL TRUST in the spirit of the influential study by Guiso, Sapienza, and Zingales (2009). Because the latest available data for this variable date back to 1996 and because BILATERAL TRUST is clearly endogenous to experiences in economic exchange and particularly to European integration developments in the late 1990s and 2000s, it is not surprising that this variable is of no use within the context of our study, e.g. has an insignificant coefficient. Detailed results are available from the authors upon request. Although an analysis of BILATERAL TRUST is in principle desirable and important, the lack of data prohibits its use. Given the importance of incorporating culture into finance analysis, especially in times of crisis, providing such data should receive a high priority in the research and political agenda.
} 


\subsection{Eurozone Depositing Before and During the Banking and Euro Crises}

Our interest mainly lies in comparing the impact of culture on financial integration in tranquil and turbulent periods. We first separate our panel data into a pre-crisis (1999-2007), a banking crisis period (2008-2011), and a more narrowly defined Euro crisis (2010-2011) period. In a second step, we analyze data averaged over the respective sub-periods to correct for biased standard errors in the presence of serial correlation.

In Table 4, we present the results from our panel data regressions for the full period as well as for the pre-crisis and crisis periods. The regressions use a full set of country and country-time interaction dummies as well as an overall time dummy to control for time-invariant country characteristics, timevariant country characteristics as well as for a common trend in Eurozone integration, respectively. Even for the early banking crisis (2008-2011), we can already report a substantial increase in the role of cultural borders, as shown by a cultural distance coefficient, which increases from -0.22 in the pre-crisis period to -0.37 in the crisis period, while at the same time, the importance of physical borders both in terms of quantitative impact and statistical significance diminishes. For the decision to deposit across borders, this suggests that cultural similarity improves at the expense of the physical border crossing, while the size of the home country deposit market also becomes more important. To test for the significance of the crisis effects, we re-estimate the full period (1999-2011) model introducing both a crisis dummy and a crisistimes-cultural distance dummy. While the simple crisis dummy is not significant, the increase in the cultural difference coefficient is of statistical significance. This result is robust and remains unchanged when we exclude Italy, for which the BIS does not report data on cross-border deposits received from 2009 onwards. We therefore also report the model's estimate excluding the destination country of Italy in Table 4. Furthermore, it can be argued that the full impact of the financial crisis has only been felt after the doubt over the solvency of Greece, what finally led to the Euro crisis. We therefore re-estimate the models for the 2010-2011 period, which covers the Euro crisis. Obviously, these estimates exclude Italy. They reveal that the resurgence of cultural borders is now even more severe, with a statistically significant change in the cultural distance coefficient of -0.18 , indicating that the crisis has really obtained 
a European dimension. ${ }^{19}$ We also crosscheck whether our results are biased by serial correlation and estimate the pre-crises and crises periods by averaging data over the whole sub-periods. The results of these exercises are reported in Table 5 and confirm that serial correlation does not invalidate our results. The impact of cultural distance increases, as reflected by a coefficient of -0.21 for the pre-crisis period to -0.34 and -0.37 for the banking crisis and Euro crisis periods, respectively. The slight variation in the coefficients between Table 4 and Table 5 is partly caused by the restricted sample size of the average data analyses in Table 5, which excludes Greece, Italy, and Portugal.

[Insert Tables 4 and 5 about here]

The impact of CULTURAL DISTANCE is of high economic significance. To illustrate, take the estimated point elasticity of cross-border deposit holdings in percent of the bank country's overall deposits with respect to CULTURAL DISTANCE for the 1999-2011 period in Table 5, which is -0.25 . One standard deviation higher CULTURAL DISTANCE in the sample implies a 17\% lower cross-border deposit share. ${ }^{20}$ Alternatively, one can consider different pairs of origin and destination countries: if the trust difference from the point of view of an Austrian depositor towards the Netherlands would be as low as towards Germany, this would imply an increase of the cross-border deposit share from Austria to the Netherlands by $45 \%$.

However, given that for such large differences, the estimated point elasticities might not give reliable results, we also predict our dependent variable with the 1999-2011 regression and contrast the result with the counterfactual of setting all CULTURAL DISTANCES to the sample minimum, e.g., the cultural difference between Germany and Austria. Using actual CULTURAL DISTANCES, we predict an average (median) volume of bilateral cross-border deposits in percent of total deposits of the destination

\footnotetext{
${ }^{19}$ We also estimate Table 4 using our alternative cultural proxies. However, neither the simple language and religion dummies nor the complex culture variables of the Hofstede and Casson type are significant in any of the subperiods. Detailed results are available from the authors upon request.

${ }^{20}$ This is based on an average log of CULTURAL DISTANCE of 2.30 and a standard deviation of 1.05 percentage points or $45.7 \%$ of the mean.
} 
country of $0.58 \%(0.13 \%)$. Under the assumption that all cultural differences are minimized, this average (median) cross-border deposit share for each bilateral country-pair increases to $1.03 \%(0.21 \%)$. Even in this restricted sample of only nine countries, this implies that the share of within-Eurozone cross-border deposits increases on average from $4.64 \%$ to $8.4 \%$. For the banking crisis period, we estimate an average (median) share of bilateral cross-border deposits of $0.66 \%(0.15 \%)$, which would more than double to $1.43 \%(0.24 \%)$ in the counterfactual case of minimal cultural differences. These effects are even stronger during the Euro crisis: Here, we estimate an average (median) share of cross-border deposits of $0.67 \%$ $(0.13 \%)$, which would increase to $1.55 \%(0.25 \%)$ in the counterfactual case of minimal cultural differences. $^{21}$

\subsection{The Changing Impact of Physical and Cultural Borders Over Time}

In Table 6, we report estimates over rolling three-year averaged periods. This allows us to document the changing impact of cultural and physical borders in Eurozone cross-border depositing over time while at the same time avoiding any potential problems with serial correlation. In Panel A, we report the results for a restricted common sample that excludes data for destination countries Greece, Italy, and Portugal, for which not all data on received deposits are available over the whole estimation period. The estimates thus suffer from incomplete coverage of all Eurozone countries but can provide a good insight into the development of the impact of borders over time. In line with the panel estimates shown in Table 4, the role of physical borders diminishes over time, while the size of the home deposit market becomes a quantitatively more important driver of cross-border depositing. The most striking result here is, however, that we can confirm not only the resurgence of cultural borders during the crisis periods, and in particular in the Euro crisis but also that in the years after the introduction of Euro notes, cultural differences are no longer relevant, indicating a certain "Europhoria" facilitated by the physical existence of the Euro. It is in

\footnotetext{
${ }^{21}$ The actual average (median) shares of cross-border deposits are $0.72 \%(0.12 \%)$ during the $1999-2011$ period, $0.77 \%(0.13 \%)$ during the 2008-2011 banking crisis, and 0.78\% (0.15\%) during the 2010-2011 Euro crisis.
} 
this sense that confidence in European institutions goes some way to reduce cultural borders and - of course - vice versa.

In Panel B of Table 6, we include Greece, Italy, and Portugal whenever data for the respective sub-periods are available. For the sub-periods from 1999-2001 to 2002-2004, we exclude Greece and Portugal. The estimates are rather similar to those reported in Panel A, and we conclude that the inclusion of Italy does not change the results with respect to the role of physical and cultural borders in any dramatic way. For the sub-periods from 2003-2005 to 2006-2008, only Portugal is excluded; thus, in comparison to the estimates in the previous periods, Greece is added. Not surprisingly, this has an impact on the coefficient for cultural differences, which increases a bit in both size and significance because Greece has particularly low trust levels and thus reveals a high level of cultural difference from the rest of the Eurozone. Finally, the crisis periods from 2007-2009 onwards reveal a stronger resurgence of cultural borders than that reported in Panel A for the common sample. Again, this is due to the inclusion of Greece and Portugal, which are culturally most different from the rest of the Eurozone.

In sum, the results of the rolling regressions confirm the results of the panel regressions but also reveal that the initially positive view on the Euro has helped to overcome not only physical but also cultural borders in Europe - at least if cultural differences were not perceived as too extreme, as is the case with Greece and Portugal, both of whom show relatively low trust levels. However, when confidence in the ability to contain the financial crisis vane, cultural borders resurge.

[Insert Table 6 about here]

\section{ROBUSTNESS CHECKS}

We perform two types of robustness checks. First, we investigate how our results are influenced by the choice of methodology. Second, we explore whether our results depend on variable selection. We perform both types of robustness checks for the panel regressions of Table 4 as well as for the rolling average regressions of Table 6 . 
Table 7 reports the robustness checks for our panel regressions. For reading convenience, we replicate the baseline regressions for the different sub-periods from Table 4 in bold letters. Because cultural differences are our main interest, we only report the coefficients of CULTURAL DISTANCE and the coefficient for the interaction of the crisis dummies with the CULTURAL DISTANCE coefficient. ${ }^{22}$

The first two robustness checks show that using time-invariant country dummies and a Eurozonewide time dummy does not drive our results. The same is true for alternative clustering of standard errors by year or for simple robust standard errors; this would make our results even stronger. We then continue to explore a simple COMMON BORDER dummy and BORDER POPULATION as alternatives to COMMON BORDER LENGTH. Moreover, and as suggested by Giuliano, Spilimbergo, and Tonon (2006), we replace the DISTANCE variable with measures of TRANSPORTATION COSTS. Again, our results are robust, with the exception that the interaction dummy becomes marginally insignificant for the banking crisis period when Italy is excluded. However, it can be argued that DISTANCE is a better proxy for the TRANSPORTATION COSTS of weightless products than the proxies used for merchandise trade. Next, we re-specify our SIZE variable and use GDP data to proxy for country size. We first use the combined GDPs of both countries and regress on the absolute value of cross-border deposits, and second, we simply replace the size of the origin country's deposit market with the GDP of the origin country. The results for cultural differences are robust, but GDP-based size proxies are not statistically significant in all periods. This confirms that our model, which uses the size of the respective deposit markets, is better specified. We also report regression results which control for TRADE. The results are by and large robust, but in the latter case, the interaction term for the banking crisis is only significant at the $11 \%$ level. This reduction in the significance of the CULTURAL DISTANCE is not surprising because TRADE itself is influenced by CULTURAL DISTANCE. Our specification without TRADE can therefore be understood as a reduced-form estimation of the impact of CULTURAL DISTANCE. Finally, we control for COMMON LEGAL FAMILY as suggested by La Porta et al. (1998). Again, we can also validate our results in this case.

${ }^{22}$ Detailed results are available from the authors upon request. 
We also undertake the corresponding robustness checks for our rolling period estimates. Again, the results are robust ${ }^{23}$ to all alternative specifications, as seen in Table A3 in the Appendix B. ${ }^{24}$

\section{[Insert Table 7 about here]}

\section{CONCLUSIONS}

We demonstrate that cultural differences constitute important trade costs and act as cultural borders to international finance. As such, and first, cultural differences are an important barrier to cross-border depositing. Second, we show that to quantify the impact of cultural heterogeneity on cross-border depositing, cultural distance is best measured by differences in general trust levels. Third, our disaggregated analysis shows that the positive experiences with the Euro, and the resulting "Europhoria" in the Eurozone prior to 2008 reduces the impact of cultural differences. Fourth, and most important, we are able to show that cultural borders clearly resurge during financial crises and reconfigure the geography of international banking.

In sum, our results suggest that integrating cultural variables into theoretical and empirical research on international finance should receive high priority, especially in enhancing our understanding of financial retrenchment during financial crises and the often-observed over-optimism during stable periods. With respect to future research, our study suggests that general trust-level differences can be used as a simple and easily obtained proxy for cultural heterogeneity, which could be used and eventually validated in further studies on international exchange in general and cross-border finance in particular. With respect to political implications, our study shows that cultural borders that are considered to be a thing of the past can forcefully reemerge in times of crisis. Although policymakers should acknowledge that cultural barriers have the potential to limit the effectiveness of integration policies, they nevertheless

\footnotetext{
${ }^{23}$ The exception is the estimation using GDP-based proxies for country size. As argued before, this variable is, however, inferior to our deposit market size variable and not significant in all sub-periods.

${ }^{24}$ Detailed results are available from the authors upon request.
} 
have effective instruments at their disposal: they can build confidence in institutions to overcome cultural borders.

\section{APPENDIX A}

\section{A Theoretical Gravity Model for Cross-Border Depositing}

To derive a gravity equation for cross-border depositing within a general equilibrium framework, we build on Anderson and van Wincoop's (2003) separable trade theory approach and use a one-sector-oneperiod model. Because banks offer a wide range of deposit products, we use a gravity approach with heterogeneous trade costs and heterogeneous elasticities of substitution at the product level. We consider an $N$ country world with monopolistically competitive banks that offer differentiated deposit products. Consumers in the origin country $o$ derive utility $U_{o}$ from consuming a variety $k$ of domestic and foreign deposit products, embodied in CES preferences given by:

$$
U_{o}=\left(\sum_{d=1}^{N} \beta_{d}^{k\left(1-\sigma_{k}\right) / \sigma_{k}} \cdot C_{o d}^{k\left(\sigma_{k}-1\right) / \sigma_{k}}\right)^{\sigma_{k} /\left(\sigma_{k}-1\right)}, o, d=1, \ldots, N
$$

where $\sigma$ is the elasticity of substitution with $\sigma>1$. $C_{o d}$ represents the deposits of residents of the origin country in the destination country $d$ (including domestic deposits $C_{o o}$ ) and $\beta_{j}$ is a positive distribution parameter to weight their preferences for country $d$ 's deposit products.

We use the simplifying assumption that a constant share of country $o$ 's wealth is allocated to deposits. This assumption implies that a fixed share $\gamma_{o}$ of wealth $W$ is spent on deposits $E_{o}$ and yields the budget constraint for residents of country $o$ :

$$
\gamma_{o}^{k} W_{o}^{k}=E_{o}^{k}=\sum_{d=1}^{N} p_{o}^{k} \cdot t_{o d}^{k} \cdot C_{o d}^{k}
$$

Equation (A-2) uses the simplifying assumption that the depositors purchase a deposit in $t$ at a domestic price $p_{o}$, which is below the price in $t+1$, normalized at unity. Thus, we assume a positive rate of return on one-period deposit holdings that is inversely related to $p_{o}$. Consequently, $p_{o}$ reflects bank margins, bank 
efficiency, and all types of domestic information and transaction costs borne by the depositors. We introduce trade costs into the model as a bilateral trade cost factor of Samuelson's iceberg form, $t_{o d} \geq 1$, such that $t_{o d}-1$ is the fraction of costs, primarily information and transaction costs due to foreign trade barriers. Maximizing (A-1) subject to (A-2) determines the demand for deposits of a certain variety $k$ by residents of country $o, X_{o d}^{k}$ :

$$
X_{o d}^{k}=\left(\frac{\beta_{d} p_{o}^{k} t_{o d}^{k}}{P_{o}^{k}}\right)^{1-\sigma_{k}} \cdot E_{o}^{k}
$$

where $P_{o}$ is the CES price index of country $o$ given by:

$$
P_{o}^{k}=\left[\sum_{d=1}^{N}\left(\beta_{d}^{k} \cdot p_{o}^{k} \cdot t_{o d}^{k}\right)^{\left(1-\sigma_{k}\right)}\right]^{\frac{1}{1-\sigma_{k}}}
$$

The market-clearing conditions for the deposit market in the destination country $d$ imply that prices have to adjust such that the demand for all deposits, i.e., all cross-border deposits plus the domestic deposits of residents in country $d$, equals the supply of deposit products $\left(D_{d}\right)$ :

$$
D_{d}^{k}=\sum_{o=1}^{N} X_{o d}^{k}
$$

Some algebraic manipulation yields the system:

$$
\begin{aligned}
& X_{o d}^{k}=D_{d}^{k} \cdot E_{o}^{k} \cdot\left(\frac{t_{o d}^{k}}{P_{o}^{k} \cdot \Pi_{d}^{k}}\right)^{1-\sigma_{k}} \\
& P_{o}^{k}=\left[\sum_{d=1}^{N} D_{d}^{k}\left(\frac{t_{o d}^{k}}{\Pi_{d}^{k}}\right)^{1-\sigma_{k}}\right]^{1 / 1-\sigma_{k}} \\
& \Pi_{d}^{k}=\left[\sum_{o=1}^{N} E_{o}^{k}\left(\frac{t_{o d}^{k}}{P_{o}^{k}}\right)^{1-\sigma}\right]^{1 / 1-\sigma_{k}}
\end{aligned}
$$

Equation (A-6) is the gravity equation for cross-border depositing. The price indexes given in equations (A-7) and (A-8) express the multilateral resistance. 


\section{APPENDIX B}

[Insert Tables A1 to A3 here] 


\section{LITERATURE CITED}

Adam, K, Jappelli, T, Menichini, A, Padula, M and Pagano, M. 2002: Analyse, compare, and apply alternative indicators and monitoring methodologies to measure the evolution of capital market integration in the European Union. Working Paper, Centre for Studies in Economics and Finance, University of Salerno.

Algan, Y and Cahuc, P. 2010: Inherited trust and growth. American Economic Review 100(5): 2060-2092.

Anderson, J. 1979: A theoretical foundation for the gravity equation. American Economic Review 69(1): 106-116.

Anderson, J and van Wincoop, E. 2003: Gravity with gravitas: A solution to the border puzzle. American Economic Review 93(1): 170-192.

Anderson, J and van Wincoop, E. 2004: Trade costs. Journal of Economic Literature 42(3): 691-751.

Arrow, K. 1972: Gifts and Exchanges. Philosophy and Public Affairs I: 343-362.

Aviat, A and Coeurdacier, N. 2007: The geography of trade in goods and asset holdings. Journal of International Economics 71(1): 22-51.

Baele, L, Ferrando, A, Hördahl, P, Krylova, E and Monnet, C. 2004: Measuring financial integration in the euro area. Oxford Review of Economic Policy 20(4): 509-530.

Baier, SL and Bergstrand, JH. 2009: Bonus vetus OLS: A simple method for approximating international trade-cost effects using the gravity equation. Journal of International Economics 77(1): 77-85.

Baldwin, R and Taglioni, D. 2006: Gravity for dummies and dummies for gravity equations. National Bureau of Economic Research, NBER Working Paper 12516.

Barros, PP, Berglöf, E, Fulghieri, P, Gual, J, Mazer, C and Vives, X. 2005: Integration of European Banking: The Way Forward. In: Monitoring European Deregulation 3, Centre for Economic Policy Research, London and Fundacion BBVA, Bilbao, pp. xviii-103.

Bergstrand, J. 1985: The gravity equation in international trade: Some microeconomic foundations and empirical evidence. Review of Economics and Statistics 67(3): 474-481. 
Bergstrand, J. 1989: The generalized gravity equation. Monopolistic competition and the factor proportions theory in international trade. Review of Economics and Statistics 71(1): 143-153.

Bertrand, M, Duflo, E. and Mullainathan, S. 2004: How much should we trust differences-in differences estimates? Quarterly Journal of Economics 119(1): 249-275.

Brüggemann, B, Kleinert, J and Prieto, E. 2012: A Gravity equation for bank loans. Universities of Frankfurt, Graz, and Tubingen (mimeo).

Buch, CM. 2005: Distance and international banking. Review of International Economics 13(4): 787-804.

Buch, CM and Lipponer, A. 2007: FDI versus exports: Evidence from German banks. Journal of Banking and Finance 31(3): 805-826.

Casson, M. 2006: Culture and economic performance. In: Ginsburgh, VA and Throsby, D (eds). Handbook of the Economics of Arts and Culture. Elsevier - North Holland: Amsterdam, pp. 359397.

Cetorelli, N and Goldberg, L. 2011: Global banks and international shock transmission: Evidence from the crisis. IMF Economic Review 59: 41-76.

Cetorelli, N and Goldberg, L. 2012: Banking globalization and monetary transmission. Journal of Finance 67(5): 1811-1843.

Coeurdacier, N and Martin, P. 2009: The geography of asset trade and the Euro: Insiders and outsiders. Journal of the Japanese and International Economies 23(2): 90-113.

Deardorff, A. 1998: Determinants of bilateral trade: Does gravity work in a neoclassical world? In: Frankel, J (ed). The Regionalization of the World Economy. University of Chicago Press: Chicago, pp. 7-28.

Dermine, J. 2006: European banking integration: Don't put the cart before the horse. Financial Markets, Institutions \& Instruments 15(2): 57-106.

Ekinci, MF, Kalemli-Ozcan S and Sorensen, B. 2007: Financial integration within EU countries: The role of institutions, confidence and trust. National Bureau of Economic Research, NBER Working Paper 13440. 
Feenstra, R. 2004: Advanced international trade: Theory and evidence. Princeton University Press, Princeton, NJ.

Frankel, J. 1997: Regional Trading Blocs in the World Economic System. Institute for International Economics, Washington, DC.

Giannetti, M and Laeven, L. 2012: The flight home effect: Evidence from the syndicated loan market during financial crises. Journal of Financial Economics 104(1): 23-43.

Giuliano, P, Spilimbergo, A and Tonon, G. 2006: Genetic, cultural and geographical distances. CEPR Discussion Paper No. 5807.

Grosjean, P. 2011a: The weight of history on European cultural integration: A gravity approach. American Economic Review: Papers and Proceedings 101:3: 504-508.

Grosjean, P. 2011b: The institutional legacy of the Ottoman Empire: Islamic rule and financial development South Eastern Europe. Journal of Comparative Economics 39: 1-16

Guiso, L, Sapienza, P and Zingales, L. 2006: Does culture affect economic outcomes? Journal of Economic Perspectives 20(2): 23-48.

Guiso, L, Sapienza, P and Zingales, L. 2009: Cultural Biases in Economic Exchange. Quarterly Journal of Economics 124(3): 1095-1131.

Herrmann, S and Mihaljek D. 2010: The determinants of cross-border bank flows to emerging markets: new empirical evidence on the spread of financial crises. BIS Working Papers No 315.

Heuchemer, S, Kleimeier, S and Sander, H. 2009: The determinants of cross-border lending in the Euro zone. Comparative Economic Studies 51(4): 467-499.

Hildebrand, T, Rocholl, J and Schulz, A. 2012: Flight to where? Evidence from bank investments during the financial crisis. Mimeo.

Hofstede, G. 1980: Culture's Consequences. International Differences in Work-Related Values. Sage Publications Inc: Thousand Oaks, CA. 
Kleimeier, S and Sander, H. 2006: Regional versus global integration of Eurozone retail banking markets: Understanding the recent evidence from price based integration measures. Quarterly Review of Economics and Finance 46(3): 353-368.

Kleimeier, S and Sander, H. 2007: Integrating Europe's banking market. Where do we stand? Centre for European Policy Studies Research Report on Finance and Banking, CEPS: Brussels.

Kleimeier, S, Sander, H and Heuchemer, S. 2013: Financial crises and cross-border banking: New evidence. Journal of International Money and Finance 32: 884-915.

Knack S, Keefer, P. 1997: Does social capital have an economic payoff? A cross-country investigation. Quarterly Journal of Economics, 112(4): 1251-1288.

Krugman PR. 1980: Scale economies, product differentiation, and the pattern of trade, American Economic Review 70: 950-959.

La Porta, R, Lopez-de-Silane, F, Shleifer, A and Vishny, RW. 1998: Law and finance. Journal of Political Economy 106(6): 1113-1155.

Lane, PR and Milesi-Feretti, GM. 2004: International investment patterns. IMF Working Paper WP/04/134.

Martin, P and Rey, H. 2004: Financial super-markets: size matters for asset trade. Journal of International Economics 64(2): 335-361.

Matutes, C. and Vives, X. 2000: Imperfect competition, risk taking, and regulation in banking. European Economic Review 44: 1-34.

Melitz, J. 2008: Language and Foreign Trade. European Economic Review 52(4): 667-699.

Milesi-Ferretti, GM and Tille, C. 2011: The great retrenchment: International capital flows during the global financial crisis. Economic Policy 26(66): 289-346.

Niepmann, F. 2013: Banking across borders. Federal Reserve Bank of New York Staff Reports No. 576.

Novo-Peteiro, JA. 2009: Bank mergers in spatially differentiated markets. Journal of Economics and Business 61: 90-96. 
Okawa, Y and van Wincoop, E. 2012: Gravity in international finance. Journal of International Economics 87(2): 205-215.

Peek, J and Rosengren, E. 2000: Collateral damage: effects of the Japanese bank crisis on real activity in the United States. American Economic Review 90(1): 30-45.

Pita Barros, P. 1999: Multimarket competition in banking, with an example for the Portuguese market. International Journal of Industrial Organization 17: 335-352.

Popov, A and Udell, G. 2012: Cross-border banking, credit access, and the financial crisis. Journal of International Economics 87(1): 147-161.

Portes, R and Rey, H. 2005: The determinants of cross-border equity flows. Journal of International Economics 65(2): 269-296.

Rose, AK and Wieladek, T. 2011: Financial protectionism: the first test. National Bureau of Economic Research Working Paper 17073.

Salop, S. 1979: Monopolistic competition with outside goods. Bell Journal of Economics 10(1): 141-156.

Sapienza, P, Toldra, A and Zingales, L. 2007: Understanding trust. National Bureau of Economic Research, NBER Working Paper 13387.

Shenkar, O. 2001: Cultural distance revisited: towards a more rigorous conceptualization and measurement of cultural differences, Journal of International Business Studies 32: 519-535.

Siegel, JI, Licht, AN and Schwartz, SH. 2011: Egalitarianism and international investment, Journal of Financial Economics 102: 621-642.

Stulz, RM and Williamson, R. 2003: Culture, openness, and finance, Journal of Financial Economics 70: 313-349.

Takats, E. 2010: Was it credit supply? Cross-border bank lending to emerging market economies during the financial crisis. BIS Quarterly Review (June): 49-56.

Tang, L and Koveos, PE. 2008: A framework to update Hofstede's cultural value indices: economic dynamics and institutional stability. Journal of International Business Studies 39: 1045-1063. 
Walkner, C and Raes, JP. 2005: Integration and consolidation in EU banking - An unfinished business. European Economy 226: 1-48.

Wei, SJ. 1996: Intra-national versus international trade: how stubborn are nations in global integration? National Bureau of Economic Research, NBER Working Paper 5531.

Zak, PJ and Knack, S. 2001: Trust and growth. Economic Journal 111(April): 295-321. 
TABLE 1

CROSS-BORDER DEPOSITS WITHIN THE EUROZONE

Average annual cross-border deposits

in $\%$ of total

in $€$ billion deposits

Panel A: Cross-border deposits received by banks residing in different Eurozone countries

\begin{tabular}{lrr}
\hline & & \\
Austria & 13.2 & 4.7 \\
Belgium & 64.5 & 14.4 \\
Finland & 1.4 & 1.2 \\
France & 30.0 & 2.3 \\
Germany & 89.0 & 3.5 \\
Greece $^{1}$ & 0.7 & 0.4 \\
Ireland & 30.6 & 12.3 \\
Italy & 12.6 & 1.6 \\
Luxembourg & 76.2 & 33.1 \\
Netherlands & 33.2 & 4.6 \\
Portugal & 10.8 & 5.2 \\
Spain & 25.3 & 2.2 \\
& & \\
\hline
\end{tabular}

Panel B: Cross-border deposits made by depositors residing in different Eurozone countries

\begin{tabular}{lrr}
\hline & & \\
Austria & 7.5 & 3.2 \\
Belgium & 31.8 & 9.5 \\
Finland & 8.4 & 7.5 \\
France & 35.6 & 2.6 \\
Germany & 95.2 & 3.7 \\
Greece & 3.5 & 1.9 \\
Ireland & 29.7 & 12.7 \\
Italy & 12.1 & 1.4 \\
Luxembourg & 39.9 & 20.8 \\
Netherlands & 92.5 & 13.7 \\
Portugal & 4.5 & 2.8 \\
Spain & 16.8 & 2.1 \\
\end{tabular}

Notes: This table shows descriptive statistics for bilateral retail cross-border deposits within the Eurozone. Cross-border depositing takes place when a bank in one country receives a deposit from a customer who resides in another country. Retail deposits are deposits made by households and non-financial corporations. Panel A shows the average annual cross-border deposit volume received by banks in country $\mathrm{d}$ from depositors in all other Eurozone countries o $\left(\Sigma_{\mathrm{o}} \mathrm{D}_{\mathrm{odt}}\right)$ in billions of Euros and in percent of the total deposits received by banks in country $d\left(D_{d t}\right)$ Panel B shows the average annual cross-border deposit volume made by depositors in country o with banks in all other Eurozone countries $\mathrm{d}\left(\Sigma_{\mathrm{d}} \mathrm{D}_{\text {odt }}\right)$ in billions of Euros and in percent of the total deposits made by depositors of country o (TOTAL DEPOSITS). 
TABLE 2

BILATERAL CROSS-BORDER DEPOSITS WITHIN THE EUROZONE

\begin{tabular}{|c|c|c|c|c|c|c|}
\hline \multirow[b]{2}{*}{ Year } & \multirow{2}{*}{$\begin{array}{r}\text { Total } \\
\text { cross- } \\
\text { border } \\
\text { deposits }\end{array}$} & \multicolumn{5}{|c|}{ Distribution of cross-border deposits ( $€$ million) by country-pair } \\
\hline & & Mean & $\begin{array}{r}25 \text { th } \\
\text { percentile }\end{array}$ & Median & $\begin{array}{r}75 \text { th } \\
\text { percentile }\end{array}$ & $\begin{array}{r}\text { Number of } \\
\text { observations }\end{array}$ \\
\hline 1999 & 290,360 & 742 & 25 & 103 & 364 & 110 \\
\hline 2000 & 307,800 & 736 & 28 & 101 & 325 & 110 \\
\hline 2001 & 310,410 & 704 & 32 & 110 & 369 & 110 \\
\hline 2002 & 313,310 & 726 & 35 & 113 & 410 & 110 \\
\hline 2003 & 320,720 & 662 & 28 & 90 & 380 & 121 \\
\hline 2004 & 338,990 & 674 & 26 & 95 & 442 & 121 \\
\hline 2005 & 351,000 & 659 & 25 & 100 & 417 & 121 \\
\hline 2006 & 387,260 & 646 & 22 & 100 & 466 & 121 \\
\hline 2007 & 457,290 & 674 & 21 & 123 & 430 & 132 \\
\hline 2008 & 487,140 & 671 & 20 & 91 & 463 & 132 \\
\hline 2009 & 424,850 & 678 & 24 & 108 & 433 & 121 \\
\hline 2010 & 423,910 & 648 & 26 & 132 & 484 & 121 \\
\hline 2011 & 496,140 & 707 & 30 & 146 & 483 & 121 \\
\hline All years & $4,909,180$ & 685 & 26 & 107 & 427 & 1,551 \\
\hline
\end{tabular}

Notes: This table shows descriptive statistics for bilateral retail cross-border deposits within the Eurozone. Cross-border depositing takes place when a bank in one country receives a deposit from a customer who resides in another country. Retail deposits are deposits made by households and non-financial corporations. Eurozone countries are Austria, Belgium, Finland, France, Germany, Greece, Ireland, Italy, Luxembourg, the Netherlands, Portugal, and Spain. These data on bilateral cross-border deposits are obtained on a confidential basis from the Bank of International Settlements (BIS) and are consistent with the aggregate data reported in Tables $3 \mathrm{~b}$ and $7 \mathrm{~b}$ of the publicly available BIS Locational Banking Statistics. 
TABLE 3

CULTURAL DETERMINANTS OF CROSS-BORDER DEPOSITING

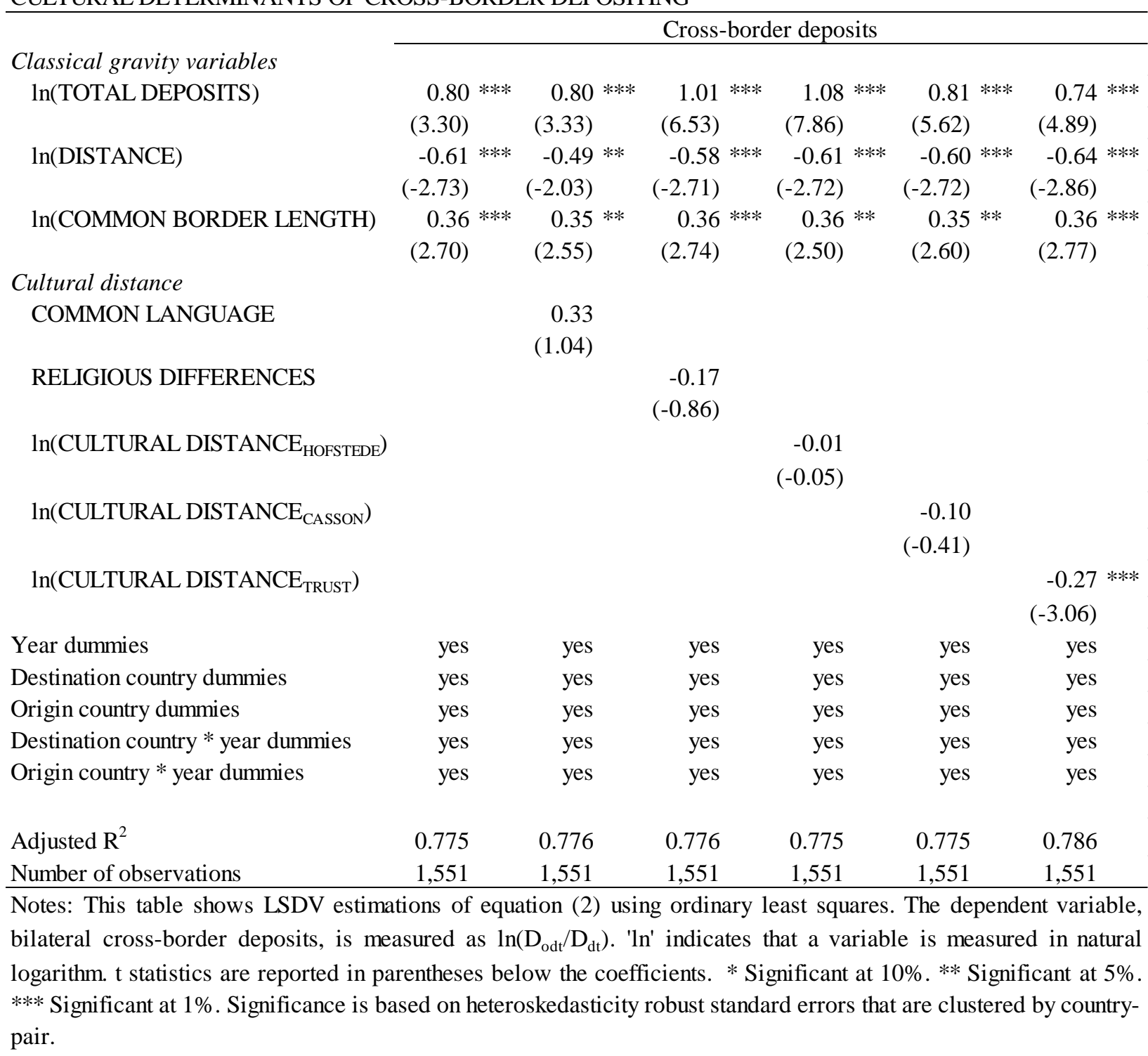


TABLE 4

CULTURAL DETERMINANTS OF CROSS-BORDER DEPOSITING BEFORE AND DURING CRISES

\begin{tabular}{|c|c|c|c|c|c|c|c|}
\hline \multirow[b]{4}{*}{ Destination countries } & \multicolumn{7}{|c|}{ Cross-border deposits } \\
\hline & \multirow[b]{2}{*}{$\begin{array}{l}\text { Full period } \\
1999-2011\end{array}$} & \multirow{2}{*}{$\begin{array}{c}\text { Pre-crisis } \\
\text { period } \\
1999-2007\end{array}$} & \multicolumn{3}{|c|}{ Banking crisis } & \multicolumn{2}{|c|}{ Euro crisis } \\
\hline & & & $\begin{array}{c}\text { Crisis period } \\
2008-2011\end{array}$ & $\begin{array}{c}\text { Full period } \\
1999-2011\end{array}$ & $\begin{array}{c}\text { Full period } \\
1999-2011\end{array}$ & $\begin{array}{c}\text { Crisis period } \\
2010-2011\end{array}$ & $\begin{array}{c}\text { Full period } \\
1999-2011\end{array}$ \\
\hline & All & All & All & All & $\begin{array}{c}\text { Excluding } \\
\text { Italy }\end{array}$ & $\begin{array}{c}\text { Excluding } \\
\text { Italy }\end{array}$ & $\begin{array}{c}\text { Excluding } \\
\text { Italy }\end{array}$ \\
\hline ln(TOTAL DEPOSITS) & $\begin{array}{l}0.74 \text { *** } \\
(4.89)\end{array}$ & $\begin{array}{l}1.03 \text { *** } \\
(5.91)\end{array}$ & $\begin{array}{l}1.23 \text { *** } \\
(7.76)\end{array}$ & $\begin{array}{l}0.82 \text { *** } \\
(4.15)\end{array}$ & $\begin{array}{l}1.18 \text { *** } \\
(5.25)\end{array}$ & $\begin{array}{l}1.30 \text { *** } \\
(7.36)\end{array}$ & $\begin{array}{l}0.91 * * * \\
(4.56)\end{array}$ \\
\hline $\ln ($ DISTANCE) & $\begin{array}{l}-0.64 * * * \\
(-2.86)\end{array}$ & $\begin{array}{l}-0.65 \text { *** } \\
(-2.73)\end{array}$ & $\begin{array}{l}-0.63 * * \\
(-2.46)\end{array}$ & $\begin{array}{l}-0.64 \text { *** } \\
(-2.86)\end{array}$ & $\begin{array}{l}-0.68 * * * \\
(-2.96)\end{array}$ & $\begin{array}{l}-0.54 * \\
(-1.90)\end{array}$ & $\begin{array}{l}-0.68 * * * \\
(-2.95)\end{array}$ \\
\hline $\ln (\mathrm{COMMON}$ BORDER LENGTH) & $\begin{array}{l}0.36 \text { *** } \\
(2.77)\end{array}$ & $\begin{array}{l}0.40 \text { *** } \\
(3.01)\end{array}$ & $\begin{array}{l}0.28 * \\
(1.77)\end{array}$ & $\begin{array}{l}0.36 \text { *** } \\
(2.77)\end{array}$ & $\begin{array}{l}0.37 * * * \\
(2.68)\end{array}$ & $\begin{array}{l}0.30 * \\
(1.70)\end{array}$ & $\begin{array}{l}0.37 \text { *** } \\
(2.68)\end{array}$ \\
\hline $\ln$ (CULTURAL DISTANCE) & $\begin{array}{l}-0.27 \text { *** } \\
(-3.06)\end{array}$ & $\begin{array}{l}-0.22 * * \\
(-2.22)\end{array}$ & $\begin{array}{l}-0.37 * * * \\
(-4.20)\end{array}$ & $\begin{array}{l}-0.22 * * \\
(-2.21)\end{array}$ & $\begin{array}{l}-0.22 * * \\
(-2.07)\end{array}$ & $\begin{array}{l}-0.41 \text { *** } \\
(-4.37)\end{array}$ & $\begin{array}{l}-0.24 * * \\
(-2.46)\end{array}$ \\
\hline CRISIS $_{\mathrm{D}}$ & & & & $\begin{array}{r}-1.00 \\
(-0.98)\end{array}$ & $\begin{array}{r}-0.08 \\
(-0.09)\end{array}$ & & $\begin{array}{l}-0.91 * \\
(-1.72)\end{array}$ \\
\hline $\ln \left(\right.$ CULTURAL DISTANCE) $*$ CRISIS $_{\mathrm{D}}$ & & & & $\begin{array}{l}-0.15 * \\
(-1.70)\end{array}$ & $\begin{array}{l}-0.15 * \\
(-1.68)\end{array}$ & & $\begin{array}{l}-0.18 * \\
(-1.92)\end{array}$ \\
\hline Year dummies & yes & yes & yes & yes & yes & yes & yes \\
\hline Destination country dummies & yes & yes & yes & yes & yes & yes & yes \\
\hline Origin country dummies & yes & yes & yes & yes & yes & yes & yes \\
\hline Destination country $*$ year dummies & yes & yes & yes & yes & yes & yes & yes \\
\hline Origin country $*$ year dummies & yes & yes & yes & yes & yes & yes & yes \\
\hline Adjusted $\mathrm{R}^{2}$ & 0.786 & 0.780 & 0.799 & 0.786 & 0.796 & 0.795 & 0.795 \\
\hline Number of observations & 1,551 & 1,056 & 495 & 1,551 & 1,441 & 242 & 1,441 \\
\hline
\end{tabular}

Notes: This table shows LSDV estimations of equation (2) using ordinary least squares. The dependent variable, bilateral cross-border deposits, is measured as $\ln \left(\mathrm{D}_{\mathrm{odt}} / \mathrm{D}_{\mathrm{dt}}\right)$. 'In' indicates that a variable is measured in natural logarithm. $\mathrm{t}$ statistics are reported in parentheses below the coefficients. $*$ Significant at $10 \%$. ** Significant at 5\%.*** Significant at $1 \%$. Significance is based on heteroskedasticity robust standard errors that are clustered by country-pair. 
TABLE 5

CULTURAL DETERMINANTS OF CROSS-BORDER DEPOSITING BEFORE AND DURING CRISES USING AGGREGATE DATA

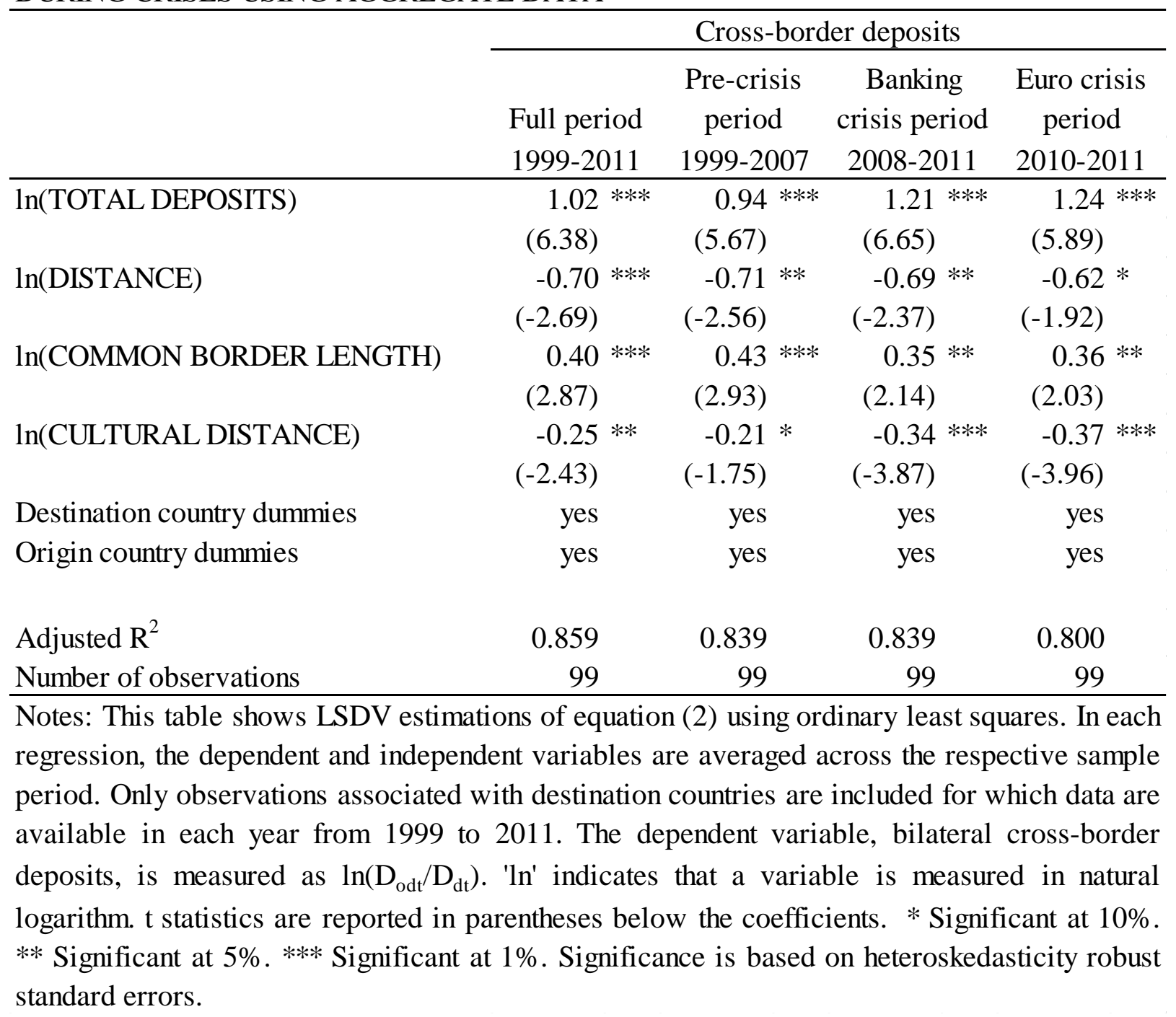


TABLE 6

CHANGES IN THE CULTURAL DETERMINANTS OF CROSS-BORDER DEPOSITS OVER TIME

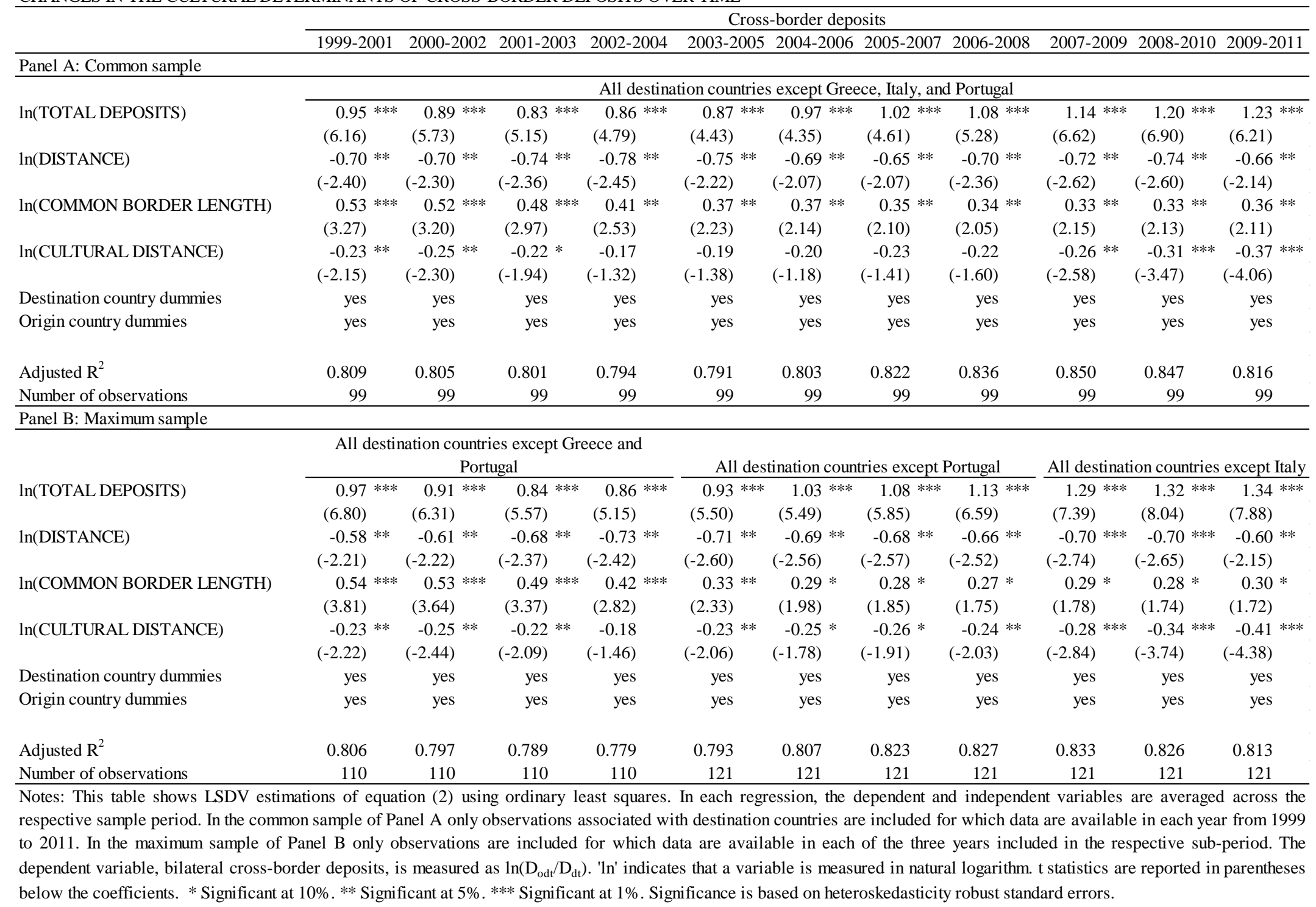


TABLE 7

ROBUSTNESS CHECKS REGARDING THE CULTURAL DETERMINANTS OF CROSS-BORDER DEPOSITS

\begin{tabular}{|c|c|c|c|c|c|c|c|}
\hline \multirow[b]{3}{*}{ Period } & \multicolumn{7}{|c|}{ Cross-border deposits } \\
\hline & & Pre-crisis & & Banking crisis & & Euro c & crisis \\
\hline & $\begin{array}{l}\text { Full period } \\
1999-2011\end{array}$ & $\begin{array}{c}\text { period } \\
1999-2007\end{array}$ & $\begin{array}{c}\text { Crisis period } \\
2008-2011\end{array}$ & $\begin{array}{c}\text { Full period } \\
1999-2011\end{array}$ & $\begin{array}{c}\text { Full period } \\
1999-2011\end{array}$ & $\begin{array}{c}\text { Crisis period } \\
2010-2011\end{array}$ & $\begin{array}{l}\text { Full period } \\
1999-2011\end{array}$ \\
\hline Destination countries & All & All & All & All & $\begin{array}{l}\text { Excluding } \\
\text { Italy }\end{array}$ & $\begin{array}{l}\text { Excluding } \\
\text { Italy }\end{array}$ & $\begin{array}{l}\text { Excluding } \\
\text { Italy }\end{array}$ \\
\hline \multicolumn{8}{|l|}{ Baseline regressions: } \\
\hline $\ln$ (CULTURAL DISTANCE) & $\begin{array}{l}-0.27 * * * \\
(-3.06)\end{array}$ & $\begin{array}{l}-0.22 * * \\
(-2.22)\end{array}$ & $\begin{array}{l}-0.37 * * * \\
(-4.20)\end{array}$ & $\begin{array}{l}-0.22 * * \\
(-2.21)\end{array}$ & $\begin{array}{l}-0.22 * * \\
(-2.07)\end{array}$ & $\begin{array}{l}-0.41 * * * \\
(-4.37)\end{array}$ & $\begin{array}{l}-0.24 \\
(-2.46)\end{array}$ \\
\hline $\ln \left(\right.$ CULTURAL DISTANCE)* CRISIS $_{\mathrm{D}}$ & & & & $\begin{array}{l}-0.15 * \\
(-1.70)\end{array}$ & $\begin{array}{c}-0.15 \text { * } \\
(-1.68)\end{array}$ & & $\begin{array}{c}-0.18 * \\
(-1.92)\end{array}$ \\
\hline \multicolumn{8}{|c|}{ Regressions without destination and origin country dummies: } \\
\hline $\ln$ (CULTURAL DISTANCE) & $\begin{array}{l}-0.27 \text { *** } \\
(-3.06)\end{array}$ & $\begin{array}{l}-0.22 \text { ** } \\
(-2.22)\end{array}$ & $\begin{array}{l}-0.37 \text { *** } \\
(-4.20)\end{array}$ & $\begin{array}{l}-0.22 \text { ** } \\
(-2.21)\end{array}$ & $\begin{array}{l}-0.22 \text { ** } \\
(-2.07)\end{array}$ & $\begin{array}{l}-0.41 * * * \\
(-4.37)\end{array}$ & $\begin{array}{l}-0.24 * * \\
(-2.46)\end{array}$ \\
\hline $\ln \left(\right.$ CULTURAL DISTANCE)*CRISIS ${ }_{\mathrm{D}}$ & & & & $\begin{array}{l}-0.15 \text { * } \\
(-1.70)\end{array}$ & $\begin{array}{l}-0.15 * \\
(-1.68)\end{array}$ & & $\begin{array}{c}-0.18 * \\
(-1.92)\end{array}$ \\
\hline \multicolumn{8}{|c|}{ Regressions without year dummies, destination and origin country dummies: } \\
\hline $\ln ($ CULTURAL DISTANCE) & $\begin{array}{l}-0.27 * * * \\
(-3.06)\end{array}$ & $\begin{array}{l}-0.22 \text { ** } \\
(-2.22)\end{array}$ & $\begin{array}{l}-0.37 \text { *** } \\
(-4.20)\end{array}$ & $\begin{array}{l}-0.22 * * \\
(-2.21)\end{array}$ & $\begin{array}{l}-0.22 * * \\
(-2.07)\end{array}$ & $\begin{array}{l}-0.41 * * * * \\
(-4.37)\end{array}$ & $\begin{array}{l}-0.24 * * \\
(-2.46)\end{array}$ \\
\hline $\ln \left(\right.$ CULTURAL DISTANCE)*CRISIS ${ }_{\mathrm{D}}$ & & & & $\begin{array}{l}-0.15 \text { * } \\
(-1.70)\end{array}$ & $\begin{array}{l}-0.15 \text { * } \\
(-1.68)\end{array}$ & & $\begin{array}{c}-0.18 * \\
(-1.92)\end{array}$ \\
\hline \multicolumn{8}{|c|}{ Regressions with robust standard errors clustered by year: } \\
\hline $\ln ($ CULTURAL DISTANCE) & $\begin{array}{l}-0.27 \text { *** } \\
(-9.20)\end{array}$ & $\begin{array}{l}-0.22 \text { *** } \\
(-10.45)\end{array}$ & $\begin{array}{l}-0.37 \text { *** } \\
(-7.35)\end{array}$ & $\begin{array}{r}-0.22 \\
(-10.63)\end{array}$ & $\begin{array}{l}-0.22 \text { **** } \\
(-10.52)\end{array}$ & $\begin{array}{c}-0.41 * \\
(-7.12)\end{array}$ & $\begin{array}{l}-0.24 \text { *** } \\
(-9.69)\end{array}$ \\
\hline $\ln \left(\right.$ CULTURAL DISTANCE)*CRISIS ${ }_{\mathrm{D}}$ & & & & $\begin{array}{l}-0.15 * * \\
(-2.90)\end{array}$ & $\begin{array}{l}-0.15 * * * \\
(-3.25)\end{array}$ & & $\begin{array}{l}-0.18 \text { **** } \\
(-3.45)\end{array}$ \\
\hline \multicolumn{8}{|l|}{ Regressions with robust standard errors: } \\
\hline $\ln ($ CULTURAL DISTANCE) & $\begin{array}{l}-0.27 * * * * \\
(-7.91)\end{array}$ & $\begin{array}{l}-0.22 * * * \\
(-5.28)\end{array}$ & $\begin{array}{l}-0.37 * * * \\
(-7.24)\end{array}$ & $\begin{array}{l}-0.22 \text { **** } \\
(-5.27)\end{array}$ & $\begin{array}{l}-0.22 * * * \\
(-4.99)\end{array}$ & $\begin{array}{l}-0.41 * * * * \\
(-5.71)\end{array}$ & $\begin{array}{l}-0.24 * * * \\
(-6.29)\end{array}$ \\
\hline $\ln \left(\right.$ CULTURAL DISTANCE)*CRISIS ${ }_{\mathrm{D}}$ & & & & $\begin{array}{l}-0.15 \text { ** } \\
(-2.25)\end{array}$ & $\begin{array}{l}-0.15 * * \\
(-2.30)\end{array}$ & & $\begin{array}{l}-0.18 \text { ** } \\
(-2.17)\end{array}$ \\
\hline \multicolumn{8}{|c|}{ Regressions in which In(COMMON BORDER LENGTH) is replaced with COMMON BORDER: } \\
\hline In(CULTURAL DISTANCE) & $\begin{array}{l}-0.26 * * * \\
(-2.84)\end{array}$ & $\begin{array}{l}-0.21 \text { ** } \\
(-2.02)\end{array}$ & $\begin{array}{l}-0.36 \text { **** } \\
(-3.98)\end{array}$ & $\begin{array}{l}-0.21 \text { ** } \\
(-2.05)\end{array}$ & $\begin{array}{l}-0.21 * \\
(-1.90)\end{array}$ & $\begin{array}{l}-0.41 * * * \\
(-4.14)\end{array}$ & $\begin{array}{l}-0.23 \text { ** } \\
(-2.27)\end{array}$ \\
\hline $\ln \left(\right.$ CULTURAL DISTANCE)*CRISIS ${ }_{\mathrm{D}}$ & & & & $\begin{array}{l}-0.15 * \\
(-1.72)\end{array}$ & $\begin{array}{l}-0.16 * \\
(-1.73)\end{array}$ & & $\begin{array}{c}-0.18 * \\
(-1.95)\end{array}$ \\
\hline \multicolumn{8}{|c|}{ Regressions in which ln(COMMON BORDER LENGTH) is replaced with $\ln (B O R D E R$ POPULATION): } \\
\hline $\ln ($ CULTURAL DISTANCE) & $\begin{array}{l}-0.26 \text { *** } \\
(-2.83)\end{array}$ & $\begin{array}{l}-0.21 \\
(-2.01)\end{array}$ & $\begin{array}{l}-0.36 \text { *** } \\
(-3.97)\end{array}$ & $\begin{array}{l}-0.21 \text { ** } \\
(-2.04)\end{array}$ & $\begin{array}{c}-0.20 * \\
(-1.88)\end{array}$ & $\begin{array}{l}-0.41 \text { **** } \\
(-4.15)\end{array}$ & $\begin{array}{l}-0.23 \text { ** } \\
(-2.25)\end{array}$ \\
\hline $\ln \left(\right.$ CULTURAL DISTANCE)*CRISIS ${ }_{\mathrm{D}}$ & & & & $\begin{array}{l}-0.15 * \\
(-1.73)\end{array}$ & $\begin{array}{l}-0.16 * \\
(-1.73)\end{array}$ & & $\begin{array}{c}-0.18 * \\
(-1.95)\end{array}$ \\
\hline \multicolumn{8}{|c|}{ Regressions in which $\ln (D I S T A N C E)$ is replaced with $\ln ($ LAND TRANSPORTATION COST): } \\
\hline $\ln ($ CULTURAL DISTANCE) & $\begin{array}{l}-0.29 * * * \\
(-2.91)\end{array}$ & $\begin{array}{l}-0.24 \text { ** } \\
(-2.15)\end{array}$ & $\begin{array}{l}-0.38 \text { *** } \\
(-4.09)\end{array}$ & $\begin{array}{l}-0.24 \text { ** } \\
(-2.15)\end{array}$ & $\begin{array}{l}-0.24 * * \\
(-2.01)\end{array}$ & $\begin{array}{l}-0.43 \text { *** } \\
(-4.31)\end{array}$ & $\begin{array}{l}-0.26 \text { ** } \\
(-2.36)\end{array}$ \\
\hline $\ln \left(\right.$ CULTURAL DISTANCE)*CRISIS ${ }_{\mathrm{D}}$ & & & & $\begin{array}{l}-0.15 * \\
(-1.70)\end{array}$ & $\begin{array}{r}-0.15 \\
(-1.63)\end{array}$ & & $\begin{array}{c}-0.17 \text { * } \\
(-1.87)\end{array}$ \\
\hline Regressions in which $\ln ($ DISTANCE) is $r$ & eplaced with lo & In(AIR TRANSI & ORTATION CO & OST): & & & \\
\hline $\ln ($ CULTURAL DISTANCE) & $\begin{array}{l}-0.28 \text { **** } \\
(-2.95)\end{array}$ & $\begin{array}{l}-0.24 * * \\
(-2.18)\end{array}$ & $\begin{array}{l}-0.38 * * * \\
(-4.07)\end{array}$ & $\begin{array}{l}-0.24 \text { ** } \\
(-2.18)\end{array}$ & $\begin{array}{l}-0.24 * * \\
(-2.03)\end{array}$ & $\begin{array}{l}-0.42 \text { **** } \\
(-4.25)\end{array}$ & $\begin{array}{l}-0.26 \text { ** } \\
(-2.38)\end{array}$ \\
\hline $\ln \left(\right.$ CULTURAL DISTANCE)*CRISIS ${ }_{\mathrm{D}}$ & & & & $\begin{array}{c}-0.15 \text { * } \\
(-1.69)\end{array}$ & $\begin{array}{r}-0.15 \\
(-1.62)\end{array}$ & & $\begin{array}{c}-0.17 \text { * } \\
(-1.86)\end{array}$ \\
\hline Regressions in which $\ln (T O T A L$ DEPOSI & TS) is replacec & $d$ with $\ln (S I Z L$ & odt $):$ & & & & \\
\hline $\ln$ (CULTURAL DISTANCE) & $\begin{array}{c}-0.22 \text { ** } \\
(-2.28)\end{array}$ & $\begin{array}{r}-0.17 \\
(-1.51)\end{array}$ & $\begin{array}{l}-0.33 \text { **** } \\
(-3.85)\end{array}$ & $\begin{array}{r}-0.16 \\
(-1.51)\end{array}$ & $\begin{array}{r}-0.16 \\
(-1.38)\end{array}$ & $\begin{array}{l}-0.37 \text { *** } \\
(-4.04)\end{array}$ & $\begin{array}{c}-0.19 * \\
(-1.75)\end{array}$ \\
\hline $\ln \left(\right.$ CULTURAL DISTANCE)*CRISIS ${ }_{\mathrm{D}}$ & & & & $\begin{array}{l}-0.17 \text { ** } \\
(-2.21)\end{array}$ & $\begin{array}{l}-0.19 * * \\
(-2.28)\end{array}$ & & $\begin{array}{l}-0.19 \text { ** } \\
(-2.32)\end{array}$ \\
\hline Regressions in which $\ln (T O T A L$ DEPOSI & TS) is replacec & $d$ with $\ln (S I Z t$ & & & & & \\
\hline $\ln ($ CULTURAL DISTANCE) & $\begin{array}{l}-0.27 \text { *** } \\
(-3.06)\end{array}$ & $\begin{array}{l}-0.22 * * \\
(-2.22)\end{array}$ & $\begin{array}{l}-0.37 * * * \\
(-4.20)\end{array}$ & $\begin{array}{l}-0.22 * * \\
(-2.21)\end{array}$ & $\begin{array}{l}-0.22 * * \\
(-2.07)\end{array}$ & $\begin{array}{l}-0.41 * * * \\
(-4.37)\end{array}$ & $\begin{array}{l}-0.24 * * \\
(-2.46)\end{array}$ \\
\hline $\ln \left(\right.$ CULTURAL DISTANCE)*CRISIS $_{\mathrm{D}}$ & & & & $\begin{array}{c}-0.15 * \\
(-1.70)\end{array}$ & $\begin{array}{c}-0.15 * \\
(-1.68)\end{array}$ & & $\begin{array}{c}-0.18 * \\
(-1.92)\end{array}$ \\
\hline
\end{tabular}




\begin{tabular}{|c|c|c|c|c|c|c|c|}
\hline & \multicolumn{7}{|c|}{ Cross-border deposits } \\
\hline & \multirow[b]{2}{*}{ Full period } & \multirow{2}{*}{$\begin{array}{c}\text { Pre-crisis } \\
\text { period }\end{array}$} & \multicolumn{3}{|c|}{ Banking crisis } & \multicolumn{2}{|c|}{ Euro crisis } \\
\hline & & & Crisis period & Full period & Full period & Crisis period & Full period \\
\hline Period & 1999-2011 & 1999-2007 & $2008-2011$ & 1999-2011 & 1999-2011 & 2009-2011 & 1999-2011 \\
\hline & & & & & Excluding & Excluding & Excluding \\
\hline
\end{tabular}

\begin{tabular}{|c|c|c|c|c|c|c|c|}
\hline Destination countries & All & All & All & All & Italy & Italy & Italy \\
\hline \multicolumn{8}{|l|}{ Regressions in which $\ln (T R A D E)$ is added: } \\
\hline $\ln (\mathrm{CULTURAL}$ DISTANCE) & $\begin{array}{l}-0.22 * * \\
(-2.36)\end{array}$ & $\begin{array}{l}-0.18 * \\
(-1.74)\end{array}$ & $\begin{array}{l}-0.31 * * * \\
(-3.01)\end{array}$ & $\begin{array}{l}-0.18 * \\
(-1.71)\end{array}$ & $\begin{array}{r}-0.18 \\
(-1.58)\end{array}$ & $\begin{array}{l}-0.36 * * * \\
(-3.26)\end{array}$ & $\begin{array}{l}-0.20 * \\
(-1.89)\end{array}$ \\
\hline $\ln \left(\right.$ CULTURAL DISTANCE)*CRISIS ${ }_{\mathrm{D}}$ & & & & $\begin{array}{l}-0.14 * \\
(-1.68)\end{array}$ & $\begin{array}{l}-0.15 * \\
(-1.70)\end{array}$ & & $\begin{array}{l}-0.17 * \\
(-1.89)\end{array}$ \\
\hline \multicolumn{8}{|c|}{ Regressions in which COMMON LEGAL FAMILY is added: } \\
\hline $\ln (\mathrm{CULTURAL}$ DISTANCE) & $\begin{array}{l}-0.23 * * * \\
(-2.66)\end{array}$ & $\begin{array}{l}-0.18 * \\
(-1.85)\end{array}$ & $\begin{array}{l}-0.33 * * * \\
(-3.83)\end{array}$ & $\begin{array}{l}-0.18 * \\
(-1.90)\end{array}$ & $\begin{array}{l}-0.18 * \\
(-1.73)\end{array}$ & $\begin{array}{l}-0.39 * * * \\
(-4.06)\end{array}$ & $\begin{array}{l}-0.20 * * \\
(-2.07)\end{array}$ \\
\hline $\ln \left(\right.$ CULTURAL DISTANCE)*CRISIS ${ }_{\mathrm{D}}$ & & & & $\begin{array}{r}-0.14 \\
(-1.61) \\
\end{array}$ & $\begin{array}{l}-0.15 * \\
(-1.67)\end{array}$ & & $\begin{array}{l}-0.17 * \\
(-1.91)\end{array}$ \\
\hline
\end{tabular}

Notes: This table shows LSDV estimations of equation (2) using ordinary least squares. The baseline regressions are identical to the regressions shown in Table 4 while the remaining regressions provide robustness checks regarding alternative dependent variables or alternative standard errors. For all regressions only the coefficients associated with our cultural proxy are reported. The dependent variable, bilateral cross-border deposits, is measured as $\ln \left(\mathrm{D}_{\text {odt }} / \mathrm{D}_{\mathrm{dt}}\right)$ with one exception: When $\ln ($ TOTAL DEPOSITS $)$ is replaced with $\ln \left(\mathrm{SIZE}_{\text {odt }}\right)$, then the dependent variable is measured as $\ln \left(\mathrm{D}_{\text {odt }}\right)$. 'In' indicates that a variable is measured in natural logarithm. $\mathrm{t}$ statistics are reported in parentheses below the coefficients. * Significant at $10 \%$. ** Significant at 5\%. *** Significant at $1 \%$. Significance is based on heteroskedasticity robust standard errors that are - unless otherwise indicated - clustered by country-pair. 
TABLE A1

DESCRIPTION OF VARIABLES

\begin{tabular}{ll}
\hline variable & details and source \\
\hline $\mathrm{D}_{\text {odt }}$ & Outstanding volume of bank liabilities (deposits) of banks in country d vis-à-vis the non-bank sector in country o in \\
& billions of Euros in year t. Source: Bank of International Settlements, Locational Banking Statistics (confidential). \\
& Converted from US dollar to euro using the exchange rate obtained from IFS, series EMQ..AE.
\end{tabular}

$\mathrm{D}_{\mathrm{dt}}$

Outstanding volume of bank liabilities (deposits) reported by banks in country d vis-à-vis the non-bank sector including residents from country $d$ and non-residents from all other countries o worldwide in millions of euro in year t. Source: Bank of International Settlements, Locational Banking Statistics, table 3b for non-resident deposits. ESCB Statistics on "Domestic and cross-border positions of MFIs (Monetary Financial Institutions): outstanding amounts"; series 1.1.1.2 for domestic deposits. Non-resident deposits are converted from US dollar to euro using the exchange rate obtained from IFS, series EMQ..AE

TOTAL DEPOSITS

Outstanding volume of bank liabilities (deposits) of the non-bank sector in country o with banks in country o and all other BIS reporting countries d in billions of Euros in year t. Source: Bank of International Settlements, Locational Banking Statistics, table 7b for non-resident deposits. ESCB Statistics on "Domestic and cross-border positions of MFIs (Monetary Financial Institutions): outstanding amounts"; series 1.1.1.2 for domestic deposits. Non-resident deposits are converted from US dollar to euro using the exchange rate obtained from IFS, series EMQ..AE.

$\mathrm{SIZE}_{\text {odt }}$

GDP of country o times GDP of country d in billions of Euros in year t. Source: Eurostat's series ESNGDPA for all countries except Greece and Luxembourg, for which series 99B..A from the IMF's IFS are used.

$\mathrm{SIZE}_{\text {ot }}$ GDP of country o in billions of Euros in year t. Source as above.

DISTANCE

Distance in $\mathrm{km}$ between the capital cities of countries o and d. Source: http://www.chemical-ecology.net/java/latlong.htm.

LAND TRANSPORTATION Transportation cost by land between countries o and d for freight of $1000 \mathrm{~kg}$ of all kinds with no special handling. Source: COST Import Export Wizard LLC, http://importexportwizard.com/, download November 2, 2012

AIR TRANSPORTATION COST

Transportation cost by air between countries o and $\mathrm{d}$ for freight of $1000 \mathrm{~kg}$ of all kinds with no special handling. Source: Import Export Wizard LLC, http://importexportwizard.com/, download November 2, 2012.

COMMON BORDER

Length of common land border between countries o and d in km. Source: CIA World Factbook

LENGTH

COMMON BORDER

BORDER POPULATION

Dummy equal to 1 if countries o and d have a common land border, 0 otherwise. Source: CIA World Factbook.

COMMON LANGUAGE

Population on 1 January by age and sex - NUTS 2 regions [demo_r_d2jan].

Dummy equal to 1 if countries o and $\mathrm{d}$ share a common language. The following countries have a common language: Germany-Austria, Belgium-France, Belgium-Netherlands, Austria-Luxembourg, Belgium-Luxembourg, GermanyLuxembourg, France-Luxembourg. Source: Own calculations.

RELIGIOUS DIFFERENCES

CULTURAL DISTANCE ${ }_{\text {HOFSTEDE }}$

CULTURAL DISTANCE ${ }_{\text {CASSON }}$

CULTURAL DISTANCE $_{\text {TRUST }}$

CULTURAL DISTANCE TRADE
Indicator variable based on the country-specific levels of the predominant Christian religion. A country is considered predominantly Catholic if more than $50 \%$ of population is Catholic in 2000. Correspondingly for Protestant and Orthodox. A country is considered 'mixed' if more than 50\% of population is either Catholic or Protestant in 2000 but each group alone accounts for less than $50 \%$. The index of religious differences is coded as 0 if countries o and d have the same predominant religion; 1 if country o is mixed but country $d$ is predominantly Catholic or Protestant, and vice versa; and 2 if countries o and d have different predominant religions. Source: Religion - R. Barro's Religion Adherence Data, http://rbarro.com/data-sets/.

Cultural index based on the four cultural dimensions by Hofstede (uncertainty avoidance, masculinity, individualism, power distance). Measured as Euclidean distance between country o and d. Source: http://www.geert-hofstede.com hofstede_dimensions.php?culture $1=86 \&$ culture $2=18$ Appeal

Cultural index based on three cultural dimensions by Hofstede (uncertainty avoidance, masculinity, individualism) and trust. Measured as Euclidean distance between country o and d. Source as above.

Percentage of respondents that answer affirmative to question A 165 of the World Value Survey: "Most people can be trusted". Measured as the Euclidean distance between the trust levels of countries o and d. The data reflect 1999 except for Finland where the data reflect 2000. Source: World Values Survey, 2006: European and World Values Surveys FourWave Integrated Data File, 1981-2004, v.20060423, 2006; http://www.worldvaluessurvey.org/.

Our preferred cultural distance proxy; measured as CULTURAL DISTANCE TRUST $_{\text {. }}$

Exports from country o to country $\mathrm{d}$ and imports into country o from country $\mathrm{d}$ in year $\mathrm{t}$ in millions of euro at current prices calculated as (exports odt + imports $\left._{\text {odt }}\right)$. Source: IMF's Direction of Trade Statistics. Import and exports are originally reported in US dollar and converted to euro using the exchange rate obtained from the IFS, series EMQ..AE.

Dummy equal to 1 if countries o and d belong to same legal family, 0 otherwise. Source: La Porta et al. (1998). 
TABLE A2

TRUST AND TRUST DIFFERENCES IN THE EUROZONE

\begin{tabular}{|c|c|c|c|c|c|c|c|c|c|c|c|c|c|}
\hline & Austria & Belgium & Finland & France & ermany & Greece & Ireland & Italy & $\begin{array}{r}\text { Luxem- } \\
\text { bourg } \\
\end{array}$ & $\begin{array}{r}\text { Nether- } \\
\text { lands }\end{array}$ & Portugal & Spain & Average \\
\hline \multicolumn{14}{|c|}{ Panel A: Level of trust } \\
\hline Trust & 33.9 & 30.8 & 58.1 & 22.2 & 34.9 & 23.8 & 35.9 & 32.6 & 26.1 & 59.8 & 10.0 & 38.5 & 33.9 \\
\hline \multicolumn{14}{|c|}{ Panel B: $\ln \left(\right.$ CULTURAL DISTANCE $\left._{\text {TRUST }}\right)$} \\
\hline Austria & & 1.13 & 3.19 & 2.46 & 0.00 & 2.31 & 0.69 & 0.26 & 2.05 & 3.25 & 3.17 & 1.53 & 1.82 \\
\hline Belgium & 1.13 & & 3.31 & 2.15 & 1.41 & 1.95 & 1.63 & 0.59 & 1.55 & 3.37 & 3.03 & 2.04 & 2.01 \\
\hline Finland & 3.19 & 3.31 & & 3.58 & 3.14 & 3.54 & 3.10 & 3.24 & 3.47 & 0.53 & 3.87 & 2.98 & 3.09 \\
\hline France & 2.46 & 2.15 & 3.58 & & 2.54 & 0.47 & 2.62 & 2.34 & 1.36 & 3.63 & 2.50 & 2.79 & 2.40 \\
\hline Germany & 0.00 & 1.41 & 3.14 & 2.54 & & 2.41 & 0.00 & 0.83 & 2.17 & 3.21 & 3.21 & 1.28 & 1.84 \\
\hline Greece & 2.31 & 1.95 & 3.54 & 0.47 & 2.41 & & 2.49 & 2.17 & 0.83 & 3.58 & 2.62 & 2.69 & 2.28 \\
\hline Ireland & 0.69 & 1.63 & 3.10 & 2.62 & 0.00 & 2.49 & & 1.19 & 2.28 & 3.17 & 3.25 & 0.96 & 1.94 \\
\hline Italy & 0.26 & 0.59 & 3.24 & 2.34 & 0.83 & 2.17 & 1.19 & & 1.87 & 3.30 & 3.12 & 1.77 & 1.88 \\
\hline Luxembourg & 2.05 & 1.55 & 3.47 & 1.36 & 2.17 & 0.83 & 2.28 & 1.87 & & 3.52 & 2.78 & 2.52 & 2.22 \\
\hline Netherlands & 3.25 & 3.37 & 0.53 & 3.63 & 3.21 & 3.58 & 3.17 & 3.30 & 3.52 & & 3.91 & 3.06 & 3.14 \\
\hline Portugal & 3.17 & 3.03 & 3.87 & 2.50 & 3.21 & 2.62 & 3.25 & 3.12 & 2.78 & 3.91 & & 3.35 & 3.17 \\
\hline Spain & 1.53 & 2.04 & 2.98 & 2.79 & 1.28 & 2.69 & 0.96 & 1.77 & 2.52 & 3.06 & 3.35 & & 2.27 \\
\hline
\end{tabular}

Notes: This table shows values for our CULTURAL DISTANCE proxy based on trust. In Panel A, we show the trust level in each country. The number reflects how many people affirmatively answer the WVS question "Do you trust others?". Panel B shows the ln(CULTURAL DISTANCE $\mathrm{T}_{\mathrm{TRUST}}$ ) proxy as used in our regressions. 
TABLE A3

ROBUSTNESS CHECKS CHANGES IN THE CULTURAL DETERMINANTS OF CROSS-BORDER DEPOSITS OVER TIME

\begin{tabular}{|c|c|c|c|c|c|c|c|c|c|c|c|}
\hline & \multicolumn{11}{|c|}{ Cross-border deposits } \\
\hline & 1999-2001 & $2000-2002$ & $2001-2003$ & 2002-2004 & $2003-2005$ & $2004-2006$ & $2005-2007$ & $2006-2008$ & $2007-2009$ & $2008-2010$ & 2009-2011 \\
\hline \multicolumn{12}{|l|}{ Baseline regressions: } \\
\hline \multirow[t]{2}{*}{$\ln ($ CULTURAL DISTANCE) } & $-0.23 * *$ & $-0.25 * *$ & $-0.22 *$ & -0.17 & -0.19 & -0.20 & -0.23 & -0.22 & $-0.26 * *$ & $-0.31 * * *$ & $-0.37 * * *$ \\
\hline & $(-2.15)$ & $(-2.30)$ & $(-1.94)$ & $(-1.32)$ & $(-1.38)$ & $(-1.18)$ & $(-1.41)$ & $(-1.60)$ & $(-2.58)$ & $(-3.47)$ & $(-4.06)$ \\
\hline \multicolumn{12}{|c|}{ Regressions in which In(COMMON BORDER LENGTH) is replaced by COMMON BORDER: } \\
\hline \multirow[t]{2}{*}{$\ln$ (CULTURAL DISTANCE) } & $-0.20 *$ & $-0.21 *$ & -0.19 & -0.15 & -0.16 & -0.18 & -0.21 & -0.21 & $-0.25 * *$ & $-0.29 * * *$ & $-0.35 * * *$ \\
\hline & $(-1.76)$ & $(-1.93)$ & $(-1.64)$ & $(-1.12)$ & $(-1.20)$ & $(-1.06)$ & $(-1.30)$ & $(-1.47)$ & $(-2.36)$ & $(-3.16)$ & $(-3.71)$ \\
\hline \multicolumn{12}{|c|}{ Regressions in which $\ln (C O M M O N$ BORDER LENGTH) is replaced by $\ln ($ BORDER POPULATION): } \\
\hline \multirow[t]{2}{*}{$\ln$ (CULTURAL DISTANCE) } & $-0.19 *$ & $-0.20 *$ & -0.18 & -0.14 & -0.16 & -0.17 & -0.21 & -0.20 & $-0.24 * *$ & $-0.29 * * *$ & $-0.35 * * *$ \\
\hline & $(-1.75)$ & $(-1.92)$ & $(-1.63)$ & $(-1.10)$ & $(-1.18)$ & $(-1.04)$ & $(-1.28)$ & $(-1.45)$ & $(-2.34)$ & $(-3.14)$ & $(-3.70)$ \\
\hline \multicolumn{12}{|c|}{ Regressions in which $\ln (D I S T A N C E)$ is replaced by $\ln ($ LAND TRANSPORTATION COST): } \\
\hline \multirow[t]{2}{*}{$\ln$ (CULTURAL DISTANCE) } & $-0.25 * *$ & $-0.26 * *$ & $-0.23 *$ & -0.19 & -0.20 & -0.21 & -0.25 & -0.24 & $-0.28 * *$ & $-0.33 * * *$ & $-0.39 * * *$ \\
\hline & $(-2.05)$ & $(-2.17)$ & $(-1.86)$ & $(-1.33)$ & $(-1.40)$ & $(-1.22)$ & $(-1.45)$ & $(-1.62)$ & $(-2.49)$ & $(-3.36)$ & $(-4.08)$ \\
\hline \multicolumn{12}{|c|}{ Regressions in which $\ln (D I S T A N C E)$ is replaced with $\ln ($ AIR TRANSPORTATION COST): } \\
\hline \multirow[t]{2}{*}{$\ln$ (CULTURAL DISTANCE) } & $-0.25 * *$ & $-0.26 * *$ & $-0.23 *$ & -0.19 & -0.20 & -0.21 & -0.24 & -0.24 & $-0.28 * *$ & $-0.33 * * *$ & $-0.38 * * *$ \\
\hline & $(-2.08)$ & $(-2.20)$ & $(-1.89)$ & $(-1.35)$ & $(-1.42)$ & $(-1.23)$ & $(-1.45)$ & $(-1.62)$ & $(-2.51)$ & $(-3.38)$ & $(-4.07)$ \\
\hline \multicolumn{12}{|c|}{ Regressions in which $\ln \left(T O T A L\right.$ DEPOSITS) is replaced with $\ln \left(S I Z E_{\text {odt }}\right)$ : } \\
\hline \multirow[t]{2}{*}{$\ln ($ CULTURAL DISTANCE) } & -0.17 & -0.18 & -0.14 & -0.08 & -0.10 & -0.12 & -0.17 & -0.18 & $-0.24 * *$ & $-0.29 * * *$ & $-0.33 * * *$ \\
\hline & $(-1.32)$ & $(-1.48)$ & $(-1.17)$ & $(-0.65)$ & $(-0.81)$ & $(-0.82)$ & $(-1.16)$ & $(-1.42)$ & $(-2.35)$ & $(-3.27)$ & $(-3.90)$ \\
\hline \multicolumn{12}{|c|}{ Regressions in which $\ln (T O T A L$ DEPOSITS $)$ is replaced with $\ln \left(S I Z E_{o t}\right)$ : } \\
\hline \multirow[t]{2}{*}{$\ln ($ CULTURAL DISTANCE) } & $-0.23 * *$ & $-0.25 * *$ & $-0.22 *$ & -0.17 & -0.19 & -0.20 & -0.23 & -0.22 & $-0.26 * *$ & $-0.31 * * *$ & $-0.37 * * *$ \\
\hline & $(-2.15)$ & $(-2.30)$ & $(-1.94)$ & $(-1.32)$ & $(-1.38)$ & $(-1.18)$ & $(-1.41)$ & $(-1.60)$ & $(-2.58)$ & $(-3.47)$ & $(-4.06)$ \\
\hline \multicolumn{12}{|c|}{ Regressions in which $\ln (T R A D E)$ is added: } \\
\hline \multirow[t]{2}{*}{$\ln$ (CULTURAL DISTANCE) } & -0.18 & $-0.19 *$ & -0.16 & -0.11 & -0.12 & -0.13 & -0.16 & -0.14 & -0.18 & $-0.23 * *$ & $-0.29 * * *$ \\
\hline & $(-1.48)$ & $(-1.68)$ & $(-1.38)$ & $(-0.82)$ & $(-0.82)$ & $(-0.77)$ & $(-0.97)$ & $(-0.96)$ & $(-1.55)$ & $(-2.28)$ & $(-2.96)$ \\
\hline \multicolumn{12}{|c|}{ Regressions in which COMMON LEGAL FAMILY is added: } \\
\hline \multirow[t]{2}{*}{$\ln$ (CULTURAL DISTANCE) } & $-0.21 *$ & $-0.22 * *$ & -0.17 & -0.11 & -0.12 & -0.13 & -0.19 & -0.19 & $-0.25 * *$ & $-0.29 * * *$ & $-0.36 * * *$ \\
\hline & $(-1.87)$ & $(-2.03)$ & $(-1.60)$ & $(-0.90)$ & $(-0.95)$ & $(-0.80)$ & $(-1.12)$ & $(-1.32)$ & $(-2.29)$ & $(-3.14)$ & $(-3.79)$ \\
\hline
\end{tabular}

Notes: This table shows LSDV estimations of equation (2) using ordinary least squares. In each regression, the dependent and independent variables are averaged across the respective sample period. Only observations associated with destination countries are included for which data are available in each year from 1999 to 2011 . The baseline regressions are identical to the regressions shown in Panel A of Table 6 while the remaining regressions provide robustness checks regarding alternative dependent variables or alternative standard errors. For all regressions only the coefficients associated with our cultural proxy are reported. The dependent variable, bilateral cross-border deposits, is measured as $\ln \left(\mathrm{D}_{\text {odt }} / \mathrm{D}_{\mathrm{dt}}\right)$ with one exception: When $\ln ($ TOTAL DEPOSITS $)$ is replaced with $\ln \left(\mathrm{SIZE}_{\text {odt }}\right)$, then the dependent variable is measured as $\ln \left(\mathrm{D}_{\text {odt }}\right)$. 'In' indicates that a variable is measured in natural logarithm. $\mathrm{t}$ statistics are reported in parentheses below the coefficients. * Significant at $10 \%$. ** Significant at $5 \%$. *** Significant at $1 \%$. Significance is based on heteroskedasticity robust standard errors. 